\title{
Corporate Governance Mechanisms and Firms' Performance: An Empirical Analysis of Firms Listed on the Saudi Stock Exchange
}

\author{
Hamad Yuosef Alhumoudi \\ $\mathrm{PhD}$ Student at University of Essex \\ United Kingdom \\ Email: hamad.1992@hotmail.com
}

Received: March 19, 2016 Accepted: September 15, 2016 Published: October 03, 2016

doi:10.5296/ijafr.v6i2.9192 URL: http://dx.doi.org/10.5296/ijafr.v6i2.9192

\begin{abstract}
This study examines whether implementation of internal CG mechanisms have affected the performance of non-financial firms listed on the Saudi stock exchange "Tadawul", since the implementation of Saudi CG code. A cross-sectional regression analysis is employed on a sample of 118 non-financial Saudi firms in 2014, to test the hypotheses set out in the study. Board characteristics assessed include, board size, board composition, board meetings and CEO duality. Ownership structures include managerial and concentrated ownership. The study's empirical findings show board size and CEO duality, are amongst those board characteristics with a positive influence on firm performance. In the case of the second internal mechanisms of $\mathrm{CG}$ ownership structures, the findings suggest only managerial ownership positively affects performance. The study findings conclude that CG structures differ in every country, as each has its own social and regulations situation. The study contributes to existing literature about the $\mathrm{CG}$ in Saudi Arabia by reviewing the impact of CG practices eight years after the CGC. It enhances understanding among practitioners of $\mathrm{CG}$, and explains how it influences firm performance in Saudi.
\end{abstract}

Keywords: Capital Market Authority (CMA), Chairman of the Board (COB) , Chief Executive Officer (CEO) Corporate Governance (CG), Corporate Governance Code (CGC), Firm Performance (FP), Return on Assets (ROA), Return on Equity (ROE) 


\section{Mll Macrothink}

International Journal of Accounting and Financial Reporting

ISSN 2162-3082

2016, Vol. 6, No. 2

\section{Introduction}

Recently there have been studies worldwide, focusing on the role and execution of corporate governance (CG). This trend gained momentum in response to corporate scandals and the downfall of several of large global corporations, including Enron (2001) and World Com (2002). In addition, the worldwide financial crisis that occurred in mid-2008, and the Dubai crisis, which led to the downfall of the largest company in Dubai, have further emphasised the need to adopt CG practices. CG stresses transparency and accountability, which are essential to reassure investors and those with sources of capital funds, and to attain financial security and stability. Uncertainty and risk are pertinent factors in today's business environment, because of increasing competitiveness.

The contemporary business environment makes it difficult to anticipate and regulate elements that have an impact on companies' performance (Shleifer and Vishny, 2000). However, uncertainty and risk can be decreased through application of satisfactory CG procedures, meaning it has a significant effect in practical terms (Ghabayen, 2012). The adequacy of existing CG procedures relate to the subject of various discussions, even in developed markets (Weir et al, 2002). This is why CG guidelines have been formulated by governing international organisations like the ICGN and the OECD. For example, the OECD published a guideline for improved CG in 1998 called "Principle of Corporate Governance"; this was then re-evaluated in 2004. These standards address performance relative to long-term economics and improvements in financial structures across the globe.

In theory, $\mathrm{CG}$ is presumed to improve the performance of a company and secure the interests of its shareholders. In addition, good CG practices can create a positive relationship between a company and its wider business environment, drawing in new investors and capital funds. Adherence to good CG practices leads to improved performance, and supports effective internal governance and supervision of management.

One theory, commonly associated with CG is agency theory, which asserts that an organisation involves an arrangement between principals and agents, whereby agents, on the principals' behalf, carry out a particular service with the principals delegating a portion of the decision-making authority to agents (Daily et al, 2003). According to the CG literature, there are two aspects of agency theory; firstly, a firm's operations involving two parties, the managers and its shareholders, and the consistent maintenance of their interests. Secondly, agency theory presupposes that humans are interested only in personal gain, and are unwilling to subjugate their personal interests to those of other people (Jensen and Meckling, 1976). Thus, management (agents) normally act in their own interests and do not implement the most appropriate actions in the interests of the public or their shareholders.

\subsection{Problem Statement}

The key motivation informing the design of this dissertation is the need to study the impact of internal CG mechanisms in Saudi listed firms. This need was heightened following the Saudi financial crisis in 2005, when prospective investors lost faith in existing accounting processes (Becht et al, 2002). The crisis prompted the introduction of detailed CG regulations by the 


\section{MlMacrothink}

International Journal of Accounting and Financial Reporting

ISSN 2162-3082

2016, Vol. 6, No. 2

CMA, which is responsible for the workings of the stock market, in late 2006 (Hussainey and Nodel, 2009).

As a consequence of the new regulatory environment, it is now mandatory for all Saudi-listed firms to adopt some provisions of the corporate governance code (CGC) (i.e. Article 9, Disclosure in in the Board of director's report, Article 10, Main function of board of director's, Article 12 Formation of the board and so on). The CGC is unanimously accepted as a solution to the problems that arise in the business environment, making CG the theme of several studies carried out in the fields of economics, accounting, and the administrative and legal field. The aim of these studies has been to illuminate the benefits and positive impacts of CG (Shleifer and Vishny, 2000). The way a firm's performance (FP) is influenced by CG has been formerly studied by a number of authors (e.g. Jensen and Meckling, 1976;Elmehdi, 2007;Carcello, 2002;Ramdani and Witteloosuijn, 2009), who assert that satisfactory CG, can assist a company to better manage and allocate its resources and improve its performance, which will then have a substantial impact on its share price and enhance a shareholder's wealth (Bartholomeusz and Tanewski, 2006).

The studies carried out to date to determine the association between CG practices and FP have been undertaken in the context of both developing and developed nations. The results of these studies are, however, inconsistent. In several of the studies conducted it was found that improved FP is associated with good CG (Siala et al, 2009; Nazlinmum, 2010; Nuryanah and Islam, 2011; Cheng et al., 2008); however, others have reported a negative association between CG and FP (Yermack, 1996; Hermalin and Weisbach, 2003; Guest, 2009). Meanwhile, other studies found no significant association between the implementation of CG practices and FP (Daily and Dalton, 1992; Brickley et al, 1997; Jackling and Johl, 2009). The majority of these studies have concentrated on emerging markets without fully compensating for the fact that developing markets follow different sets of rules to developed ones (Ghabayen, 2012). In reference to this, Mousa and Desoky (2012b), caution that the CG practices used in developed markets cannot always be successfully applied to emerging markets because of cultural variations, economic factors etc. In the Saudi context, there is a body of research into how CG practices affect FP, which has created a justification and motivation for carrying out this study. Saudi regulations concentrate on the significance of internal CG practices, particularly those linked to board and ownership structures. Additionally, several articles have been made mandatory for firms listed on the stock market, requiring compliance and disclosure of CG information in their annual reports (cma.org.sa).

\subsection{Research Aim}

The aim of this study is to examine whether internal CG mechanisms have affected the performance of firms listed on the Saudi stock exchange, since the implementation of the Saudi CGC. The study will examine two dimensions effecting internal CG mechanisms: (1) board characteristics; and (2) ownership structure and its relationship with firm performance (FP). Therefore, the set of sub questions to be addressed is as follows: 


\section{Macrothink \\ International Journal of Accounting and Financial Reporting \\ ISSN 2162-3082 \\ 2016, Vol. 6, No. 2}

\subsection{Research Questions}

1. What is the current practice of the CGC in Saudi Arabia?

2. Do diverse types of board characteristics impact the performance of firms listed on the Saudi Stock Exchange?

3. Do diverse ownership structures impact the performance of firms listed on the Saudi Stock Exchange?

\subsection{Research Objectives}

1. To review the current practice of the Saudi CGC.

2. To examine the relationship between board's characteristics and FP.

3. To examine the relationship between ownership structure and FP.

\subsection{Contribution of the research}

To the best of the researcher's knowledge, internal CG mechanisms and their impact on FP has not been adequately studied in the Middle East, specifically in Saudi Arabia. Hence, this study contributes to the existing literature pertaining to CG in Saudi Arabia, by providing an overview of CG practices in the Kingdom, eight years on from publication of the CGC. The paper also aims to enhance understanding of CG, as it is a relatively new concept in Saudi Arabia. The study also seeks to improve on the understanding of practitioners with respect to how CG procedures impact FP in Saudi Arabia. In addition, it contributes to the wider field of international research into $\mathrm{CG}$.

\subsection{Scopes and Method of Research}

The research method used in this study will be quantitative in nature, relying on an Ordinary Least Square (OLS) regression to assess data acquired from 2014, because this period allows access to data on the impact of internal mechanisms of CG on FP. The annual report published by the Tadawul shows 168 firms were listed on the stock exchange in 2014, from which a sample comprising 118 non-financial corporations was selected for the study (Lucy, 2002). Financial firms are not considered in this study, because of the variations in policies linked to banks and non-financial organisations (Mehran et al., 2011).

\section{Literature Review}

The foremost aim of this chapter is to examine and evaluate the scope of CG from diverse distinct angles. In addition, the chapter discusses essential theories like agency theory and the role it plays in potential conflicts between shareholders (owners) and the managers who control organisations. However, the significance of CG will be analysed in relation to the conflicts that occurred before the pervasive implementation of CGC, including the collapse of Enron and Barings Bank. The literature will also review and discuss, the introductions of Saudi stock market, the Saudi CGC and related issues. Finally, several empirical studies will be discussed to emphasise the relationship between CG internal mechanisms (i.e. board size, board meetings, etc.) and their impact on FP, as indicated in statistical findings. 


\subsection{Corporate Governance Concept and Importance}

\subsubsection{Definition of Corporate Governance}

The business community, policy-makers and capital market regulators are acknowledging CG to a greater extent; opining that it is a crucial force driving corporate performance (Ghabayen, 2012). The classic publication by Berle and Mean (1932), "the separation of corporate ownership from control" resulted in the initial spate of studies on CG (Ongore and Kobonyo, 2011). The notion that CG is not defined in standard terms (Fallatah and Dickens, 2012) has led authors and field experts to define it differently; hence, no standard definition of CG exists. However, (Bowen et al, 2008) states that attempts have been made to describe the term so that groups of measurable components can be obtained.

Scholars, analysts and practitioners have examined the terms 'corporate' and 'governance' separately when offering definitions of their research studies. According to Prasad (2006) and Gillan and Stark (2000), a corporation is a system comprising varied resources and components, which demand collaboration between different organisational departments. Furthermore, they have stated that CG is a process whereby effective management reflects the company's interests. These definitions provide a basic outline of what these terms mean, and communicate the fact that CG refers to the execution of effective management systems in the best interests of companies (Mallin, 2010).

According to the Cadbury Committee and the Hample Report; CG is a system guiding and regulating a firm (Gee Publishing LTD, 1998). In addition, Shleifer and Vishny (1997) considered CG to be a means of introducing methods to encourage the provision of finance to corporations to guarantee a return on their investments. Hart (1995) defined CG as an intricate series of restrictions, influencing ex-post bargaining relative to the quasi-rents developed by firms.

According to Goergen et al (2010), the foundation of CG is that it is a system for managing and meeting a company's stakeholders' interests. Furthermore, not only financial shareholders are incorporated in this idea; debt holders, customers, suppliers and employees also benefit (Samaha et al., 2012). Other researchers have shared this perspective; for instance, Zingales (1998) asserts that a company can raise the matter of the CG when two conditions are met. The first condition is when there is a conflict with respect to interests, or when an organisation is unable to connect with one or more of its members such as its staff, customers, managers or owners. The second condition is when the issues faced by the organisation, such as business costs cannot be established through agreements.

Alkhudairy (2008) claims several aspects of a corporation are considered in CG practices. Peng (2008) explained CG more broadly, identifying three main factors as extremely significant: the Board of Directors, managers, and owners. These factors are demonstrated and explained in the Peng diagram given below, and the performance of each is linked to the CGC (Peng, 2008). 
Figure 1: The Tripod of CG (Source: Peng, 2008: 323).

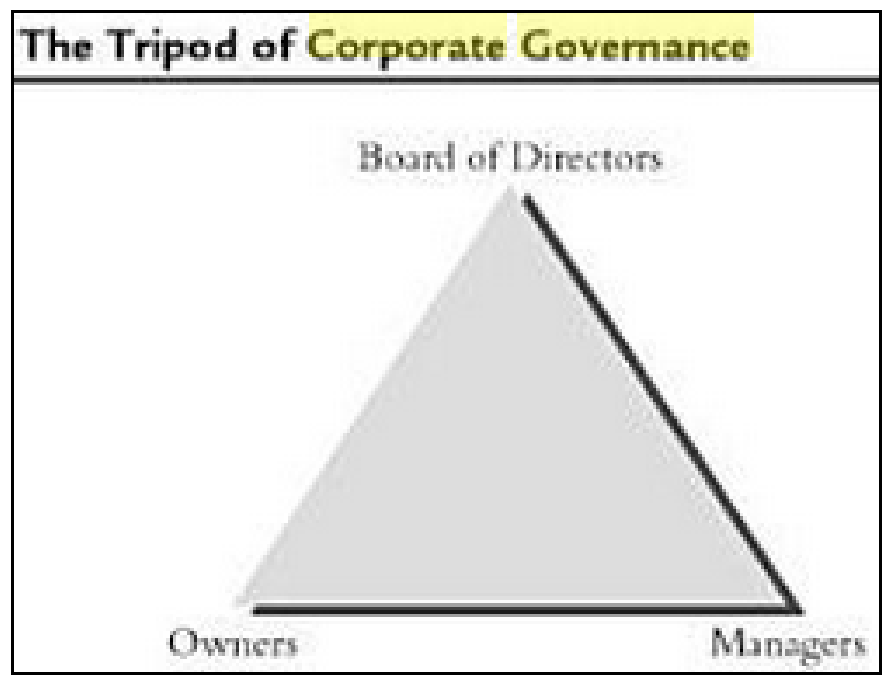

According to (La Porta et al, 2000), CG is a set of tools employed by external investors to secure their interests from within an organisation. There are likely conflicts between managers and owners, as pointed out by Bai et al. (2004) who put forward possible solutions to these kinds of conflicts. According to Sternberg (2004), CG supports the presumption that all corporate events, tools and resources are regulated to meet shareholders goals. On the other hand, (Judge et al, 2003) has argued that the interests of other shareholders should not be included in definitions of CG for two reasons. First, the term CG should only be used to denote shareholders, as they own the organisation and it exists to fulfil their interests. Second, when stakeholders are not included in a definition of CG, the rights of shareholders is not affected. Thus, it is important to apply a standard definition of CG to support understanding of the system and processes of CG (Chen, 2013). To fulfil CG requirements, it is important to apply a well-developed system of CG (Jones, 2011). However, no matter what the definition put forward, researchers frequently consider CG mechanisms to be a part of one of two classes: internal and external to the firm (Gillan and Stark, 2000).

\subsubsection{Importance of Corporate Governance}

As mentioned above, the significance of CG has increased following corporate scandals. There were several unethical corporate practices observed within European firms in the 1990s, and these ethical violations affect moral standards (Sundaram and Inkpen,2004). Ethics are crucial in all areas of business, especially where trust is required. According to Mullins (2010), ethics involves choosing whether something is good or bad, or true or false. (Agrawal and Chadha,2005) state that the corporate scandals during the 1990s negatively affected the sustainability of the entire financial market. Corporate failures, such as those of the London Merchant Bank Barings (1995), and the US firm Enron (2001), were a consequence of poor CG (Demski, 2003;Drennan, 2004; Greener, 2006; Choo, 2008). CG gained additional significance because of the deregulation and amalgamation of the capital markets. It was asserted by ICAEW that CG could generate public confidence and encourage investment, leading to better long-term economic development of the capital market. 


\section{Mll Macrothink}

International Journal of Accounting and Financial Reporting

ISSN 2162-3082

2016, Vol. 6, No. 2

Furthermore, Aljifri and Moustafa, (2007) asserts that CG can improve corporate accountability, equality and transparency.

The introduction of the capital markets and the growth of the equity markets in the European Union, particularly in view of the Euro have influenced discussions about CG (Becht et al., 2005). Various discussions have centred on the rapid development of the European Corporation, which facilitates the growth of capital market (Levine, 1999). In addition, since the beginning of the 1990s, privatisation has gained considerable importance and attracted much interest in the field of economics (Ramady, 2010). The surge toward privatisation was studied by (Megginson et al, 2001) over a twenty-year period, spanning from late the 1970s to mid-1990s. The authors found the issue of privatisation was particularly significant in most countries around the world, although less so in the USA. Furthermore, a large proportion of the earnings from privatization (approximately 64\%) were generated from Spain, France, Australia and Japan. In combination with privatisation, ownership and the topics associated with control hold great significance (Wahla et al, 2012). Bia and Peroti (2002) determined that developing and shaping policies to facilitate shareholder democracy played a major role in large scale privatisation in the UK, suggesting that good CG is central to effective privatisation.

\subsection{The Roles of $C G$}

Initial phases of CG development focused on solving the agency theory problem, enhancing transparency and assuring value to shareholders (Alkhudairy, 2008). Wei (2003) asserted that CG could generate value for stakeholders, as financial turmoil shifted focus onto the interests of shareholders, stakeholders and integration (Rezaee, 2009). Hence, the current emphasis of $\mathrm{CG}$ is on encouraging business strategies to advance businesses.

Organisational functions can be grouped into two types; i.e. whether their focus is on benefits for shareholders or benefits to stakeholders. To elaborate on this point Rezaee (2009) and Darman (2004) created two models. The first model was from shareholders' perspectives and also stakeholders' perspectives.

\subsection{Corporate Governance Theoretical Models}

\subsubsection{Agency Theory}

Conflict, as an agency problem, is much discussed by the proponents of agency theory Shapiro, (2005). Dorrenbacher (2011) states that researchers rarely use the phrase 'conflict', unless it is to describe a specific conflict, distinguishing it from the normal term "agency problem". (Thomas, 2005;Dey, 2008) have stated that conflict reflects unfavourable conditions leading to ineffectiveness, incompetency and dysfunctional results. On the other hand, Mallin (2010) put forward a discussion by (Fama and Jensen, 1983;Ramady, 2010) in which they describe agency theory as an agreement to association between principals (shareholders) and agents (manager). Hence, shareholders are the principals as the company's owners, and managers are the agents as its controllers. However, one of the main drawbacks of agency theory has been that management (that is the agents) has the option to not work in the shareholders' (that is the principals') best interests (Bai et al, 2004; Azam et al, 2011). For 


\section{MInstitute Macrothink $_{\text {Int }}$}

International Journal of Accounting and Financial Reporting ISSN 2162-3082 2016, Vol. 6, No. 2

example, the agents can avert suitable risk when using their financial power to gain benefits. The agents' decisions might then not conform to the perspectives of the principals in these situations (Almatari et al, 2012).

This behaviour is likely to be reflected in the returns generated by the firm and its performance (Leuz et al., 2003). CG mechanisms are then created to ensure agents prioritise securing the interests of shareholders and decreasing costs (Davis et al., 1997). Agency theory also serves as a foundation for the governance of an organisation in different internal and external systems (Albrecht et al, 2004; Roberts et al., 2005). According to Fama (1980), the economic objective of $\mathrm{CG}$ systems is to regulate those actions undertaken by the management. In contrast, the function of $\mathrm{CG}$ in the $\mathrm{UK}$ is to secure the interests of shareholders by monitoring managers using different means backed by the UK CG Combined Code (Weir et al., 2002).

In contrast, Solomon (2010) asserts that agents and principals have the opportunity to access different levels of information. Therefore, agents have more extensive information about their firms than principals. CG offers a system for monitoring and regulating a company to reduce conflicts or issues that might impact on shareholders (Mallin, 2010).

\subsubsection{Stakeholder Theory}

Mary Parker Follett first created the concept of stakeholder theory almost 60 years ago, however it was further developed in the 1980s (Schilling, 2000). Several later schools of research have also considered stakeholder theory; for instance, Clark (2004) asserts that a multiparty agreement is present between a business and its various stakeholders. There are formal and informal laws governing the organisational relationship between internal stakeholders like owners and managers (Lehurde et al, 2012). However, external stakeholders (like customers and suppliers) are equally significant, and there are formal and informal laws governing their relationships also (Mallin, 2010).

Nonetheless, certain authors have criticised stakeholder theory. According to Blair (1996), despite the substantial roots drawn into stakeholder theory, it has minimal impact on corporate decision-making and creativity. Furthermore, Buchholtz et al. (1998) argue that, through the stakeholder model, several participants in different areas with social or economic interests in an organisation's operations are involved such that the firm would be able to fulfil the interests of various individuals. In addition, it was also suggested in stakeholder theory that several people are linked to the organisation, such that they are affected by its decisionmaking (Gomes, 2006). According to (Freeman et al., 2004), there is a certain relationship between the goal of value generation and trade and shareholder value. Freeman et al. (2004) have concentrated on two important areas; firstly, the aim of the organizations and secondly, the responsibilities of managers to stakeholders. Stakeholder theory is hence believed to be a satisfactory expression of the interests of managers and the company.

In addition, Carver and Oliver (2002) examined stakeholder's perceptions regarding nonfinancial benefits. Although shareholders are thought to represent the financial value of the corporation, other stakeholders are also interested in gaining benefits. This means there are 


\section{Macrothink}

International Journal of Accounting and Financial Reporting

few stakeholders with non-equity stakes, with the result that managers have to manage relationships with all stakeholders, not only their shareholders (Murya, 2010). In addition, Sundaram and Inkpen (2004) opine that it is only stakeholders' value that holds significance as supports decisions making and enhances outcomes for all stakeholders. They assert that recognition of the broad category of stakeholders and their most important interests is not a practical possibility for managers.

\subsection{Background to Saudi Arabia}

The Kingdom of Saudi Arabia is situated in the South-western district of Asia in the Middle East. The Kingdom was founded by Abdulaziz bin Saud in 1932 (Alzharani et al, 2011). Other Gulf nations adjacent to the Kingdom are Bahrain, United Arab Emirates and Iraq (Vincent, 2008). The Islamic law forms the basis of the Kingdom's legal jurisdiction, and this is derived from the Holy Quran and 'Sunnah', the sayings of the Prophet Muhammad (peace be upon him) (Mead et al, 2009).

The Kingdom is the largest producer and exporter of oil, and has the greatest oil reserves in the world, amounting to $20.1 \%$ of international oil reserves. The Saudi economy is based on petroleum to a significant extent (75\%). The gross domestic product (GDP) in 2013 was calculated to be approximately $\$ 600$ billion (Worldbank.gov), and Saudi Aramco has now been the seventh biggest natural gas producer for over a decade, and is actively seeking additional reserves to fulfil increasing demand (Uddin and Tsamenyi, 2008).

\subsubsection{Saudi Arabian Stock Market}

The Saudi stock market dates to the mid-1930s with the creation of the foremost joint stock company, Arab Automobile (Alkhudairy, 2008). Subsequently, several joint stock companies were established. By December 31, 2012, 168 were companies listed on the Saudi stock exchange (Tadawul.com.sa, 2014; Uddin and Tsamenyi, 2008). A Companies Law was enacted in 1965, marking the first indication of CG in Saudi Arabia (Fallatah and Dickins, 2012). Companies Law regulated the creation of companies (public and private), governance and bankruptcy (Alzharani, 2011). The regulations associated with Companies Law, and pertaining to governance, enforced limitations on foreign ownership and the regulation of Saudi firms (Zattoni and Udge, 2012). 


\section{Macrothink}

International Journal of Accounting and Financial Reporting

ISSN 2162-3082

2016, Vol. 6, No. 2

Figure 3: Saudi Stock Exchange All Share Index 1995-2006 (Source: Tadawul Annual Report, 2006).

\section{Tadawul All Share Index [TASI] 1995 - 2005}

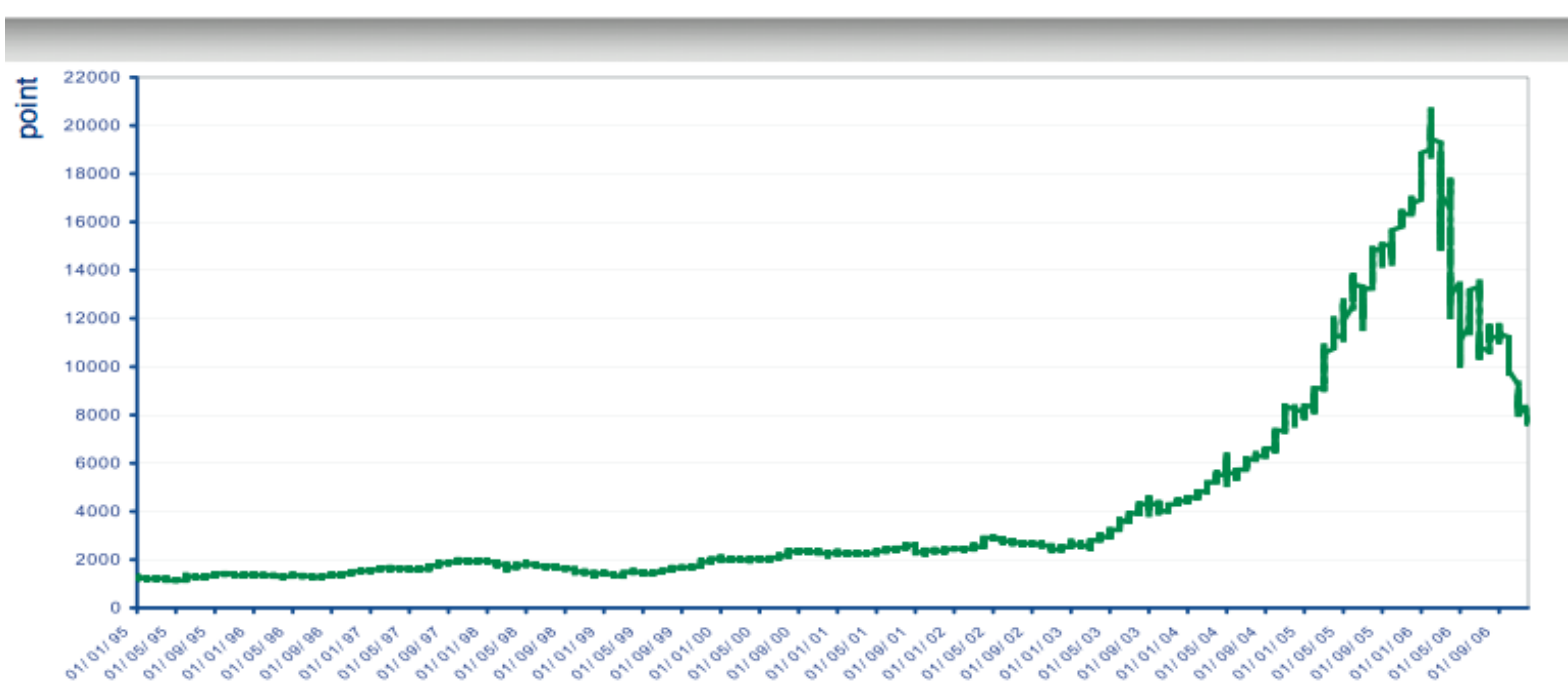

The diagram given above demonstrates a substantial decline in the Saudi stock market in 2006, when it lost 980 points in a single day (February 26, 2006). It fell again by 968 points in a single day two months later (April 10, 2006), and cumulatively declined to $48 \%$ of its complete market value. Following these events and, there was a decline in investor confidence, necessitating further corporate regulations (Ramady, 2010; Hussainey and Nodel, 2009). Consequently, the CMA, which was responsible for the workings of the stock market, implemented the CGC. At present, it is mandatory for all Saudi-listed firms to adopt some provisions of the CGC (Samba Financial Group, 2009). The conditions of the CGC require honest, impartial and fair treatment of all parties involved (Abu-Tapanjeh, 2009). This accords with the standards of the OECD (OECD, 2004) regarding all Islamic economic and primary actions (Almatari et al, 2012).

The CGC comprises Preliminary Provisions, Shareholders Rights and the General Assembly, Transparency and Disclosure, Boards of Directors and Closing Provisions (Uddin and Tsamenyi, 2008;Zattoni and Udge 2012). Regarding provisions concerning the Board of Directors, the CGC outlines the key roles and responsibilities of the board, the creation of the board, board committees, nomination and remuneration committee, the audit committee, remuneration and indemnification of board members, board meetings, and conflicts of interest within the board. The most significant terms of the CGC, which are pertinent to this study, became binding after November 10, 2008. These include: separation of COB and CEO roles, making board members independent (majority categorised as non-executive and at least one-third as independent), forming an audit committee consisting solely of non-executive members and forming a nominating and remuneration committee (Alkhudairy, 2008; Ghabayen, 2012). It was mandatory to enforce most provisions by January 1, 2011 (CMA.org.sa, 2013). 


\subsection{Empirical Studies of CG Internal Mechanisms and Firm's Performance}

\subsubsection{Board Size}

The number of directors on the board of directors determines board size (Jensen and Meckling, 1976). There has been much debate on what constitutes an appropriate size for a board of directors. Several studies assert that board size should be between 7 and 15 directors (Ogbechie et al., 2009). However, other researchers have reported ideal board size to be no more than 7 to 8 members (Jensen, 1993;Mak and Kusnadi, 2005).

The requirement of the Saudi CGC is that there should 3 to 11 members in the board of directors. These accords with Jensen's (1993) suggestion that when board size is small, FP is enhanced. He also suggests that when board size increases above 7 to 8 members, the efficiency of the board decreases and control shifts to the CEO. Ghabayen (2012) also asserted that firms with small boards function more effectively when compared to firms comprised of boards with more members. Lipton and Lorsch (1992) also investigated board size, in the US context, and found that board size in US companies is overly large, leading to increased costs for shareholders, a decrease in competitive market opportunities and job losses for employees. The authors suggest that boards should be limited to 7 or 8 members. They also disclosed that it is difficult for a board of directors to put forward their advice and suggestions when there are over 10 members on the board. (Bennedsen et al, 2008) found firms incur most costs when their board size is larger, as it has an impact on decision-making, communications and harmonisation between board directors. By contrast, (Dalton et al, 1998;Guest, 2009) stated that a larger board size leads to better decision-making, as the greater the number of directors on a board, the better the expertise of members, leading to better chances of averting corporate downfalls.

The majority of studies found a negative correlation between board size and FP (Jensen, 1993; Hermalin and Weisbach, 2003;Desoky and Mousa 2012b). Yermack (1996) examined the association between board size and FP, on 453 USA sampled companies listed on the stock exchange. The research results showed that a significant negative correlation between these factors. (Bennedsen et al, 2008) carried out another study in the Netherlands and Denmark, which investigated the association between board size and FP. The results showed a negative relationship between these two factors in both countries. Lasfer (2004) took a sample of 1402 firms listed on the German market and also found a negative association between board size and FP. Eisenberg et al. (1998) conducted a study on 900 small listed companies in the UK and found that board size and FP correlated negatively (using ROE as a measure). Another study, conducted in the Asian context, found that board size was negatively related with FP (Weir et al, 2002; Haniffa and Hudaib, 2006), mirroring findings in Switzerland, Japan and Canada (Loderer and Peyer, 2002;Adams and Mehran, 2003;Mak and Kusnadi, 2005).

Conversely, a positive relationship between board size and FP was obtained in several studies. These studies showed a large board size resulted in improved FP, because of the diverse skills and experiences present within the board members, which allowed better decisions making and supervision of the CEO's activities (Ho, 2005;Goh et al, 2014). In 
addition, (Bonn et al, 2005) investigated the association between board size and FP, testing a sample comprising 55 US listed firms over the period from 1978 to 1998. A positive relationship was obtained in their study. Other studies gave similar findings (e.g.Pfeffer, 1972;Jackling and Johl, 2009;Fallatah and Dickins, 2012;Ghabayen, 2012). Ghabayen, (2012) investigated the affect of board size on FP using 102 sampled non-financial firms listed in Saudi Arabia. He used ROA and ROE as FP measures and obtained a significant positive relationship. Also Chaghdari (2011) who examined 30 Malaysian firms and found that board size have no relationship with FP (ROA, ROE, Tobin's Q). In another study, (Shukeri et al, 2012) also obtained a significant positive association using a sample of 150 listed companies in Malaysia. These various findings may be a consequence of other variables affecting the results obtained. These variables are discussed below.

\subsubsection{Board Meeting}

Boards of directors perform important functions and are considered a vital component of CG systems (Jensen, 1993). The frequency of board meetings is a significant means of finding out how thorough and effective corporate supervision and discipline processes are (Ntim, 2009). However, similar to the issue of board size, there are multiple theoretical perspectives regarding the impact of board meetings on FP (Lipton and Lorsch, 1992;Goh et al, 2014).

One theoretical suggestion offered is that the severity of a board's functions is determined by the frequency of the board meetings, and the quality or efficacy of their monitoring (Vefeas, 1999b; Ntim and Osei, 2011). When all other aspects remain the same, a greater number of board meetings increases the quality of managerial monitoring, and hence, positively influences FP (Yusoff and Alhaji, 2012). It has also been asserted that when there are frequent meetings, directors have more time to discuss and plan strategies and evaluate managerial performance (Vafeas 1999). This allows the directors to be more aware of significant events occurring inside the company, which puts them in a better position to address critical issues as they surface (Mangena and Tauringana, 2008). In addition, frequent meetings, coupled with informal communication can develop and enhance cohesive relationships between directors (Lipton and Lorsch 1992), with a positive effect on FP. Sonnenfeld (2002) suggested frequent meetings are a trade-mark of a diligent director.

A contrasting perspective suggests few authors assert that board meetings do not always create benefits for shareholders (Elmehdi, 2007). Vefeas (1999a) claimed that the small amount of time spent by directors working together is not utilised when carrying out meaningful discussions. Rather, most of the time available for meetings is spent on routine activities like presentation of management reports and several other formalities, which decrease the time available to outside directors to effectively supervise management (Lipton and Lorsch, 1992). In addition, board meetings incur expenses for a firm in the form of managerial time, travelling costs, refreshments and meeting the charges of directors (Vafeas, 1999). These may have a negative influence on corporate performance.

Jensen asserted (1993) that the boards delivering high FP would be reasonably inactive and demonstrate minor disagreements. He claimed that instead of organising board meetings periodically, it is would be more beneficial for the board of directors to develop a framework 


\section{Mll Macrothink}

International Journal of Accounting and Financial Reporting ISSN 2162-3082 2016, Vol. 6, No. 2

that has the capacity to oversee and respond to emerging difficulties. For instance, meetings can be carried out more frequently in times of crisis, or when the interests of shareholders are funder threat, such as when bringing in a new CEO or defending hostile takeovers. This can mean the relationship between board meetings and FP could be non-linear in which case, either too few, or too many meetings, could have the same positive effect on FP (Ntim and Osei, 2011). In this scenario, the elasticity of the board either increases or decreases the frequency of meetings to manage rising challenges, rather than just the frequency, thereby affecting FP. Vafeas (1999) argues in line with Jensen's (1993) view that firms that are proficient and have the right number of meetings, based on their working situation, are likely to attain economies of scale in reducing agency costs, which would then improve FP. The author also asserted that the frequency of board meetings and board size are positively related, which is consistent with Yermack (1996), who recommended greater firm value could be attained with smaller board sizes and fewer board meetings. In addition, Vafeas (1999) investigated the impact of board meetings and FP, using a sample of 300 US companies, and found companies with fewer Board meetings have the greatest book value. The reason for this is that regular meetings indicate less efficiency and poor communication.

\subsubsection{Board Composition}

The composition of the board of directors is a vital aspect of board characteristics, and pertains to the number of outside directors on the board. Agency theory states that when a board is composed mainly of outside directors, its efficiency leads to excellent FP (Ramdani and Witteloostuijn, 2010). Previous studies have discussed board composition to a large extent, and examined the association between board composition and FP, obtaining mixed results. However, it is normally presumed that efficient boards comprise a large proportion of external directors (Ghabayen, 2012; Goh et al, 2014).

(Desoky and Mousa, 2012a) investigated the association between board composition and FP using two measurement of FP (ROE, ROA and Tobin's Q) for a sample comprising of 96 listed Egyptian firms in 2011. The findings revealed a significant positive relationship between board composition and FP. Similarly, Khan and Awan (2012) examined the same relationship in the Karachi Stock exchange, with a sample of 92 listed firms. Their results showed firms with a greater number of independent directors demonstrated a higher ROE and ROA.

O'Connell and Cramer (2010) investigated the association between board composition and FP in 80 firms listed in Ireland. They showed a positive association between board composition and FP. In addition, (Kosnik, 1987;Weiback, 1988;Kyereboah et al, 2006; Uadiale, 2010) also found a positive relationship between the percentage of external board members and FP, linking independence to improved functionality.

On the other hand, some studies have shown that when the majority of directors are independent, firms perform unsatisfactorily (Brickley et al, 1997;Bhagat and Black 2002; Ghabayen, 2012). Kiel and Nicholson (2003) examined a sample comprising 350 Australian firms, obtaining a negative relationship between board composition and FP. In addition to, some studies have been conducted to evaluate the association between board 
composition and FP using various types of performance indicators such as ROA and ROE (Hermalin and Weisbach, 1991), but empirical results failed to find any relationship.

\subsubsection{CEO Duality}

According to the agency theory, when management is separated from the board, managers are able to fulfil their responsibilities more fully and can ensure that the managers' actions are in line with the objectives of the firm and their shareholders (Faleye, 2011). Hence, chairman and CEO positions should be held by different people to insure the overall objectives of the organisation are met during the decision-making process (Fama and Jensen,1983). It has been demonstrated in several studies that companies in which the roles of Chairman and CEO are separate offer more powerful governance than companies in which the same person holds both positions (Finkelstein and Daveni, 1994). In contrast, Boyd (1995) asserts that the CEO duality and FP are negatively related to each other in respect to sales and growth.

In addition, Kula (2005) reported that when the role of Chairman was detached from that of general manager, company performance was positively influenced. This study involved 386 small and unlisted firms in Turkey. Kiel and Nicholson (2003) found a negative relationship when examining the relationship between CEO duality and FP in Australia. More recently, there was an increase in the number of regulations worldwide, which indicated a need for separation in the positions of Chairman and CEO to insure a lesser number of firm collapses (Fan, 2004). Meanwhile, other studies have demonstrated that there are weak or no associations between CEO duality and FP (Ho, 2005;Lam and Lee, 2008; Yusoff and Alhaji, 2012; Shukeri et al, 2012).

\subsubsection{Managerial Ownership and FP}

Managerial ownership central to the quality of an ownership structure, and is characterised by the percentage of shares owned by a company by insiders and boards of directors' members or internal ownership (Jaafar and EL-Shawa, 2009;Mandaci and Gumus, 2010;Almatari et al, 2012). Insider ownership functions as an efficient corporate system; although, managerial ownership is counted by Jensen and Meckling (1976) as a sign that the shareholders' interests and needs must be brought in line with those of managers.

The association between managerial ownership and FP has been investigated through theoretical and empirical proofs, delivering mixed results (Wahla et al., 2012; Khan et al, 2012). The ensuing discussion will analyse the inconclusive nature of these outcomes. Agency theory is discussed first, linked to Jensen and Meckling's (1976) finding that managerial ownership brings about an improvement in the principle-agent agency conflict, because agents own the majority of a company's shares and so have the motivation to maximize their job performance to attain an excellent performance. In contrast, high managerial ownership seems to bring about management entrenchment, leading to intense agency issues (Fama and Jensen, 1983; Khan et al, 2012).

Additionally, Jensen and Meckling (1976) and Shleifer and Vishny (1988) asserted that agency costs and managerial ownership have a negative relationship, although a positive relationship exists between FP and managerial ownership. On this subject, (Morck et al, 


\section{MInstitute Macrothink $_{\text {Int }}$}

International Journal of Accounting and Financial Reporting ISSN 2162-3082 2016, Vol. 6, No. 2

1998;Liang et al, 2011), assert that a high managerial stake in company ownership can lead to an alignment of interests between managers and owners, which will ultimately affect a firm's market value. In contrast, resource dependence theory encourages the participation of external sources, as this can offer a company a variety of sources and experiences to enhance shareholder rights and those of other parties related to the company (Khan et al, 2012). This finding concentrates on incorporating confiscated resources and integrating them, so that the highest value for experience and confiscation can be obtained, assisting in attaining the objectives of all parties associated with the company (Liang et al,2011). Hence, a high degree of ownership among board members does not bring about better firm performance (Pfeffer, 1972). Furthermore, the same outcomes are obtained in several researchers' empirical studies (Jensen and Mecking, 1976;Morck et al., 1988; Hliermalin and Weisbach, 1991), which claimed that when managers fully own the company the firm incurs no agency costs. In contrast, Fama and Jensem (1983) claimed that when there is greater managerial ownership, there are greater costs, which are not congruent with the interests of managers and shareholders. In addition, they presented a new hypothesis to discuss the negative association between managerial ownership and FP. In addition, Almatari et al. (2012) asserted that insider ownership and FP are unrelated. Researchers such as Stulz (1999) presented a different sort of association between managerial ownership and FP; i.e. one that is non-linear. This made it possible to demonstrate a positive association between insider ownership and FP, in which there is a small proportion of explanatory power ( $\mathrm{R}$ square is merely in the range of $3 \%$ and $7 \%$ ). Therefore, the association between managerial ownership and other ownerships is still unclear.

Morck et al. (1998) found a positive association when investigating the association between managerial ownership and FP. The authors determined the true purpose of managerial ownership was to establish company resources to fulfil their personal interests, which were distinct from those of external stakeholders. According to Kaplan (1989), FP can be improved upon when large manager buyouts take place. Smith (1990) reported a similar result, asserting that progress in FP may be due to paying the optional expenses of a firm; for instance, advertising, research and development, and planning and property.

\subsubsection{Concentration Ownership and FP}

The aspect of the CG system of the ownership structure, as assessed in this study, pertains to concentration ownership. It is a response to the different levels of legal security offered to minority shareholders in different countries (Almatari et al, 2012). Concentration of ownership is also described in terms of the percentage of a firm's shares retained by the majority shareholders (Azam et al., 2011). Similarly, ownership concentration is determined by the ratio of shares retained by the 5 greatest shareholders, or by the most important shareholders (Sanda et al., 2005; Karaca and Ekşi,2012).

In fact, Berle and Means (1932) found a positive association between ownership concentration and FP, although researches demonstrated a lack of association between the two variables (Demsetz and Lehn, 1985; Singh and Gaur, 2009). However, this does not reject the significance of ownership concentration, as Shleifer and Vishny (1997) asserted; 
ownership concentration, alongside legal security constitutes once of the two main factors establishing CG. That is, large shareholders can provide advantages to minority shareholders because they offer influence and incentive to prevent managers from indulging in asset stripping or expropriation. Considering this, ownership concentration can be thought of as an efficient governance scheme. Agency theory proposes that ownership concentration is a crucial element supporting better CG (Omran, 2009; Siala et al., 2009). However, when there is a high degree of ownership concentration, an opportunity to control shareholders and managers by ensuring that minority shareholders do not become involved in expropriation is provided (Bolbol et al., 2003; Obiyo and Lenee, 2011).

Keeping in view the detailed discussion presented previously regarding agency theory, empirical evidence and resource dependence theory, no conclusion has yet been reached concerning the association between ownership concentration and FP. Several international authors have stated that there is a positive correlation between ownership concentration and FP, even in developed countries (Alfarooque et al,2010). However, Shleifer and Vishney (1997) assert that FP is positively associated with a certain degree of ownership, as there is greater motivation for a larger group of block holders. Soliman (2012) reported similar results as demonstrating a powerful association between large shareholders and firm worth.

Grosfeld (2006) found a strong effect of ownership application in Japan. La Porta et al. (1999) investigated 28 developing countries and found firm's ownership structures are not well known for minority shareholder groups. Furthermore, Claessens et al. (2000) examined 3000 companies in the Middle East and Asia, and found that in over 65\% of the sampled companies, there is a single large shareholder controlling the company, because they have the majority of the shares. La Porta (1999) stated that concentration of ownership is higher in Asian countries, than in others such as Europe.

In summary, the major elements of CG have been elaborated on in the literature review in context with this research study. Various possible factors affecting FP have been introduced and the topic has referenced distinct outlooks regarding $\mathrm{CG}$, in particular its significance combined with empirical studies and essential theories (i.e. Agency theory), in order to fulfil the intentions of the critique.

\section{Research Methodology}

\subsection{Introduction}

The previous chapter reviewed the relevant theoretical and empirical literature, suggesting study designs procedures and methods, some of which have been adopted by the researcher to achieve the aim and objectives of this study. To choose an appropriate research philosophy, methodology and methods the research onion was also utilised (Saunders et al, 2009), as described herein. The main source of data is a secondary data search, which supplies a variety of information to inform the research and analytical data to support problem solving (Lucy, 2002). The study also utilises a substantial data set, collected from the annual reports of listed firms on the official stock market trading website (the Tadawul), detailing CG board structure, and ownership structures, to investigate FP (Ghabayen, 2012). In addition, 


\section{Macrothink}

International Journal of Accounting and Financial Reporting

ISSN 2162-3082

2016, Vol. 6, No. 2

secondary data studies, including journal articles, and the CG codes of Saudi Arabia will also help to enhance the study analysis.

Figure 4: The Research Onion (Source: Saunders et al, 2009:183)

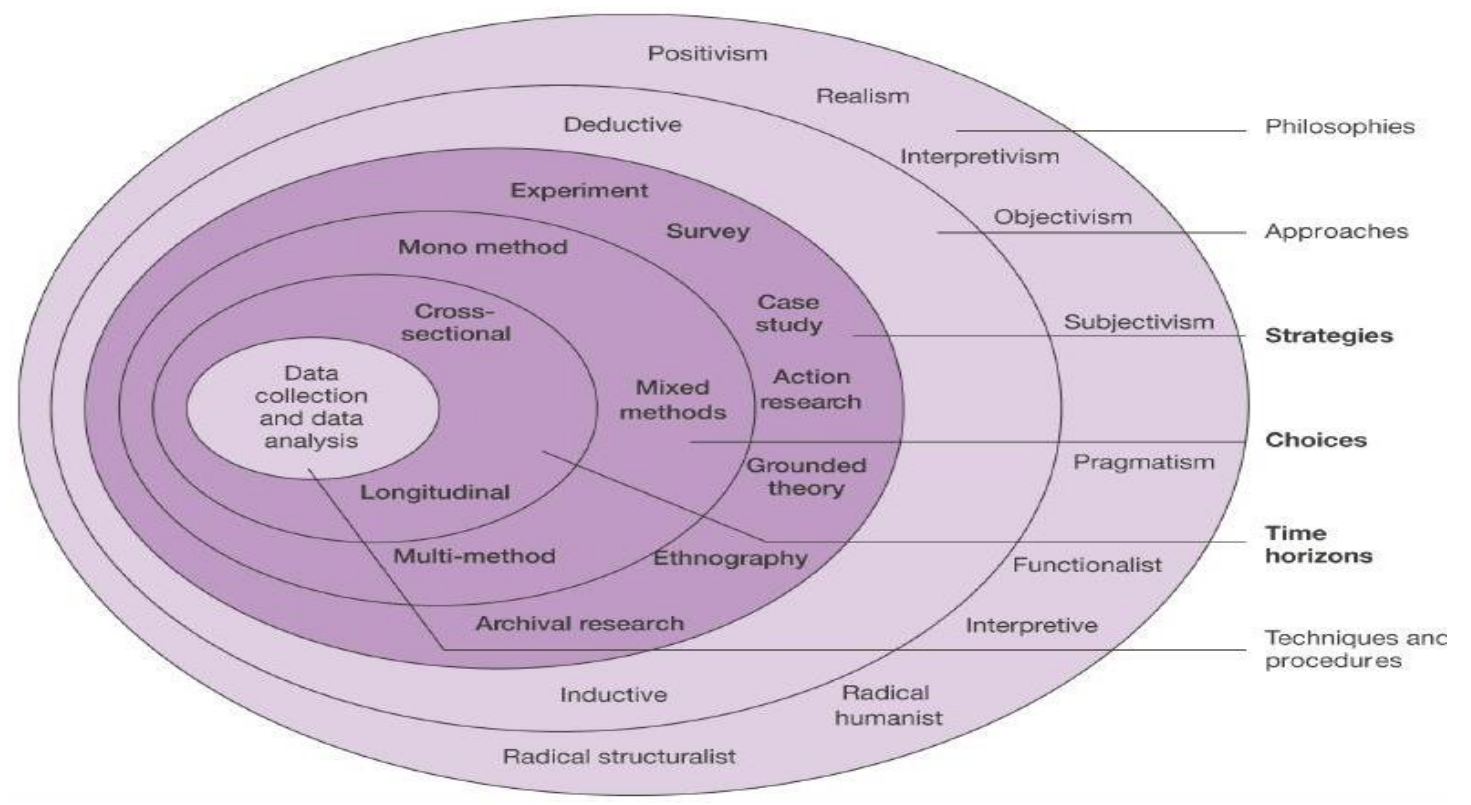

The diagram above presents various methods of research, which will be identified as:

\subsection{Research philosophy}

According to Chapman and (Giddings, 2006), there are various philosophical positions that a researcher can conveniently access. One of which is positivism, the foundation of which claims that truth is an independent and irretrievable factor, requiring the observer to not act on real assumptions or utilise the ability to uncover empirical evidence and experiments to verify the truth (Gephart, 2004).

\subsection{Research Approaches}

The research approach taken in this study will be as shown in the second layer of the socalled 'research onion' (Saunders et al., 2007). Deductive tools will be employed to support the researcher in preparing a conceptual model. By utilising a deductive approach, the researcher will be able to access a wider range of information and data, enabling generalisability, which is merely utilised in inductive studies, as conveyed by (Saunders et al, 2007). The findings collected are referred to as more convincing and trustworthy, as the quantitative data was collected utilising structured questions. The researcher made use of a deductive approach; based on an understanding of the impact of the internal CG mechanisms on FP in Saudi Arabia. 


\section{Mll Macrothink}

International Journal of Accounting and Financial Reporting

ISSN 2162-3082 2016, Vol. 6, No. 2

Figure 5: Conceptual Model (Source: Aljifri and Moustafa, 2007;Ghabayen, 2012; Khan et al, 2011)

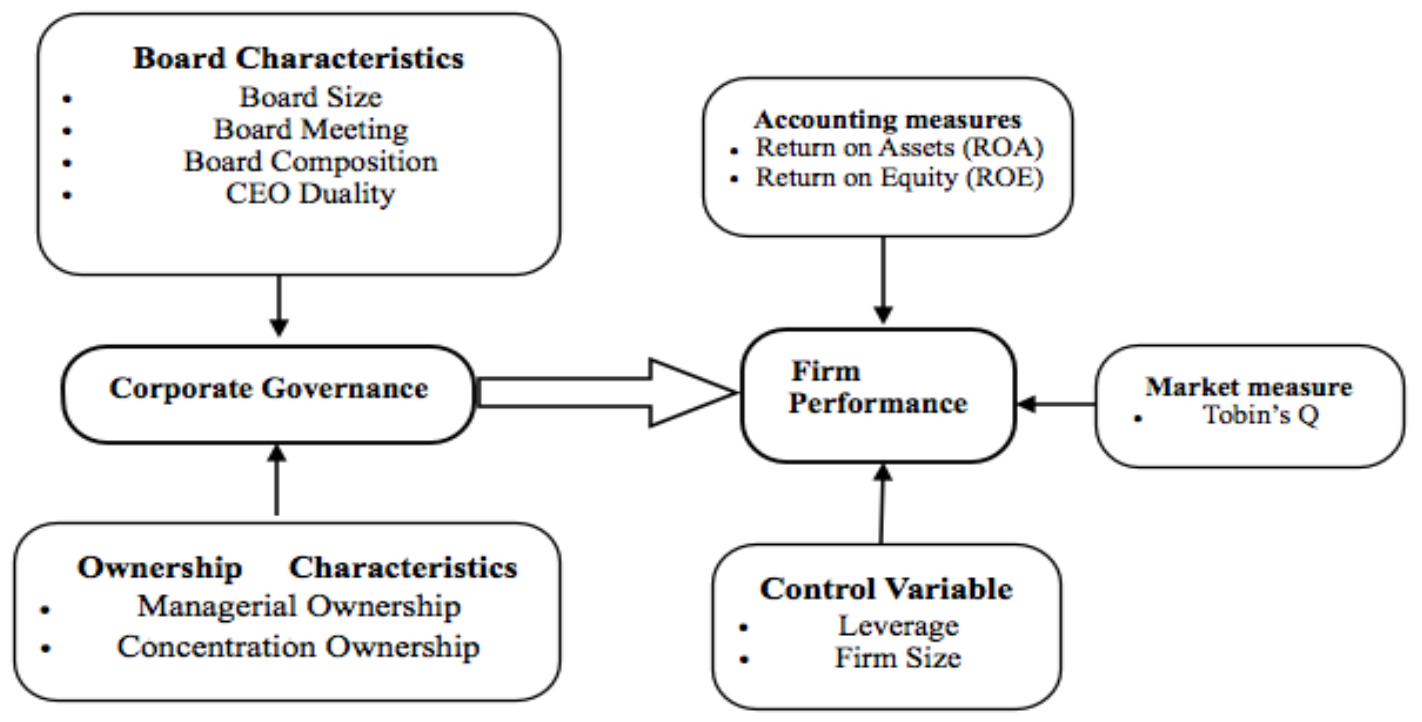

The above diagram is the conceptual model applied in this study after adaptation from the works of (Aljifri and Moustafa, 2007;Ghabayen, 2012;Khan et al, 2011). It shows that the independent variables i.e. board characteristics, including board size, board meeting, board composition and CEO duality and Ownership characteristics, including managerial and concentrated ownership are the factors determining internal governance mechanisms. The leverage and firm size are also included as independent variables, because these elements have a direct influence on FP, as depicted by the accounting measures, ROE and ROA and the market measure, Tobin's Q. These two types of measurement are utilised in prior studies to examine CG, as illustrated by (Demsets and Lehn, 1985; Yermack, 1996;Alkhouri, 2006; Yermack, 1996;Klein et al, 2005). Using these methods can have two significant consequences. Alkhouri (2006) described the first consequence, i.e. the utilisation of market measures demonstrates the extent of value and respect from investors in an organisation, while accounting measures are utilised to assess its structural form and the extent of control by accounting rules. In addition, Klein et al. (2005) described a second consequence, i.e. by means of market measures; the future of the firm can be anticipated as demonstrating market expectations, while the accounting measures help to concentrate the firm's earlier performance.

\subsection{Research Hypotheses}

Lucy (2002) explained that a hypothesis is a testable proposition, which can be useful when testing the relationship between distinct variables, if utilised empirically. Additionally, another type of hypothesis, a statistical hypothesis can be utilised for determining the probability and distribution of parameters, where probability refers to the relationship between independent and dependent variables. These are utilised to determine a null set hypothesis (H0) and an alternative (opposite) hypothesis (H1). However, hypotheses are utilised and included to identify and analyse research problems. A table is given below 


\section{Macrothink}

International Journal of Accounting and Financial Reporting

ISSN 2162-3082

comprising certain hypotheses, which have been constructed based on the findings of the preceding literature review chapter:

Table 1: Study hypotheses

\begin{tabular}{|l|l|}
\hline CG mechanism & Hypotheses \\
\hline Board size & H1: There is a relationship between board size and firm performance \\
\hline Board meeting & $\begin{array}{l}\text { H2: There is a positive relationship between board meeting and firm } \\
\text { performance }\end{array}$ \\
\hline $\begin{array}{l}\text { Board } \\
\text { composition }\end{array}$ & $\begin{array}{l}\text { H3: There is a positive relationship between board composition and firm } \\
\text { performance }\end{array}$ \\
\hline CEO duality & $\begin{array}{l}\text { H4: There is a negative relationship between CEO duality and firm } \\
\text { performance }\end{array}$ \\
\hline $\begin{array}{l}\text { Managerial } \\
\text { ownership }\end{array}$ & $\begin{array}{l}\text { H5: There is a positive relationship between managerial ownership and } \\
\text { firm performance }\end{array}$ \\
\hline $\begin{array}{l}\text { Concentration } \\
\text { ownership }\end{array}$ & $\begin{array}{l}\text { H6: There is a positive relationship between concentration ownership and } \\
\text { firm performance }\end{array}$ \\
\hline
\end{tabular}

\subsection{Research Strategies}

The third layer of the research onion is the research strategy. In order to achieve the aim and objectives of the research, an OLS regression will be conducted, to provide empirical evidence to examine the relationship (if any) between board and ownership characteristics and FP using SPSS. The data will be collected from the annual reports of listed firms on the official trading market stock website, the Tadawul. However, other secondary data resources, such as journal articles, and the CG codes of Saudi Arabia, will be used which will help to enhance the study analysis.

\subsection{Research Choice}

The fourth layer of the research onion, as proposed by Saunders et al, (2009), involves overcoming the element of choice. Moreover, the outcomes of empirical work are attained with the application of "Mono-method", along with its benefits regarding quantitative data collection techniques. However, this research option is only suitable for a single data collection technique (Saunders et al., 2009). 


\section{$\Lambda$ Macrothink}

\subsection{Time-horizon}

The time horizon in a research study refers to the amount of data presented, effecting the decision to present a long-term observation, or a snap shot of a specific point in time. While linking data to a snap shot of events, the researcher found the variables linked with the research question could be assessed using a narrow time span, something that is possible when using simultaneous data, as illustrated by Saunders et al. (2009). Therefore, the study period will be restricted to 2012 , because it was not possible to test more recent data from 2013 due to the availability of the data. Meanwhile, the 2012 period includes data to assist in examining the impact of CG internal mechanism on FP. Hence; it meets the aim and objectives of the study.

\subsection{Techniques and procedures}

\subsubsection{Data Collection}

This research study is based on a data population of non-financial firms listed on the Saudi Arabian Stock Exchange, the Tadawul (Tadawul.com.sa, 2014). (Adams and Mehran, 2003) elucidated two major discrepancies in governance, affecting the non-financial and banking sectors. The first major discrepancy is that a banks' business is relatively complicated, having the potential to alter quickly, and there are a larger number of stakeholders in a bank than in non-financial firms. As per (Almatari et al, 2012), there seems to be greater obscurity in the implementation of formal regulations within the banking sector, which complicates the financial sectors. According to (Ghayaben, 2012; Moustafa and Aljifri, 2007), financial firms are not considered here due to the discrepancies in the regulation of non-financial firms and banks. Thus, the data sample comprises data from 118 firms instead of 168, whereas the data is attained from the annual report of Tadawul, as is the number of listed organisations in 2014 (Lucy, 2002). Table A.1 in appendix A shows the firms selected for analysis.

\subsubsection{Procedures of Data Collection}

For the purpose of conducting a study on the CG mechanisms (Ownership and board characteristics) and FP, the data will be accumulated from the annual reports of the selected firms. The data sources for determining the $\mathrm{CG}$ included annual reports from the CG's corporate information and a statement and the director's profile.

Naoum (2013) stated that the secondary data was distinctive of problem solving and research. Meanwhile, the secondary data was accumulated for the purpose of leniency in accessibility, and to attain the answers to research questions; thus, all the data will be gathered from the annual reports of the listed firms on the official Tadawul website.

\subsubsection{Data Analysis}

In order to analysis the data, the multiple regression method is employed to examine the relationship between the FP in Saudi and board size, board meeting, board composition, CEO duality, managerial ownership and concentration ownership. 


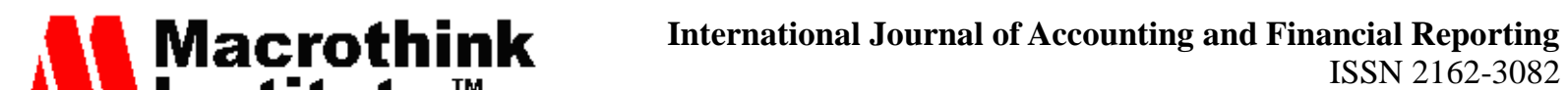 Institute ${ }^{\mathrm{TM}}$ 2016, Vol. 6, No. 2}

The result of regression analysis is a model that presents the best prediction of a dependent variable from numerous independent variables. This model is utilized when the independent variables are associated with each other's and with the dependent variable (Lucy, 2002; Ghabayen, 2012).

The following regression models that show the relationship between FP and CG internal mechanisms are estimated as follow:

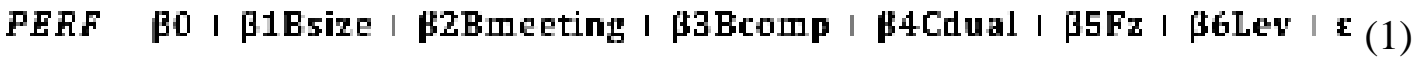

PERF BO I B1Manown । B2Cnown । B3Fz । B4Ley । E

PERF

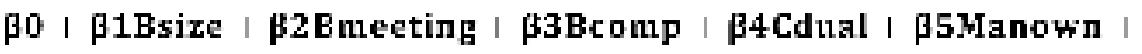
$\beta 7 \mathrm{Fz}$ । $\beta 8 \mathrm{Lev} \mid \mathrm{\varepsilon}$

(3)

The general models above will be examined using multiple regressions; the first model shows the relationship between the board characteristics only as independent variables, and FP (Tobin Q, ROA and ROE) as dependent variable. The second model shows the relationship between ownership structure only and FP. The third model shows the relationship between all internal CG mechanisms and FP. However, to clearly examine the effect of internal CG mechanisms, each of the models above will be examined twice. Firstly without including the firm size and leverage variables and secondly, which includes the firm size and leverage. Table 2 below shows the description of each variable shown in the models above and the source that will be used to collect that variable. 
Table 2: List of variables

\begin{tabular}{|c|c|c|c|c|}
\hline Type & Variable & Abbrev & Description & Source \\
\hline \multicolumn{5}{|l|}{ Independent } \\
\hline \multirow{4}{*}{$\begin{array}{c}\text { Board } \\
\text { Characteristics }\end{array}$} & Board Size & Bsize & Number of director on the board & $\begin{array}{l}\text { Annual } \\
\text { Report }\end{array}$ \\
\hline & $\begin{array}{l}\text { Board } \\
\text { Meeting }\end{array}$ & $\begin{array}{l}\text { Bmeeti } \\
\mathrm{n}\end{array}$ & $\begin{array}{l}\text { Number of Board meeting held in the last } \\
\text { accounting period reported }\end{array}$ & $\begin{array}{l}\text { Annual } \\
\text { Report }\end{array}$ \\
\hline & $\begin{array}{l}\text { Board } \\
\text { composition }\end{array}$ & Bcomp & Number of independent directors on the board & $\begin{array}{l}\text { Annual } \\
\text { Report }\end{array}$ \\
\hline & $\begin{array}{l}\text { CEO } \\
\text { Duality }\end{array}$ & Cdual & $\begin{array}{l}\text { This variable is a dummy variable, If the chairman } \\
\text { of the board is the CEO manager at the same time. If } \\
\text { yes then a value of one will be considered Otherwise } \\
\text { the value of zero should be considered. }\end{array}$ & $\begin{array}{l}\text { Annual } \\
\text { Report }\end{array}$ \\
\hline \multirow{2}{*}{$\begin{array}{l}\text { Ownership } \\
\text { Characteristics }\end{array}$} & $\begin{array}{l}\text { Managerial } \\
\text { Ownership }\end{array}$ & Mnown & $\begin{array}{l}\text { The proportion that managers and board of director } \\
\text { own in the firm }\end{array}$ & $\begin{array}{l}\text { Tadawul } \\
\text {.com.sa }\end{array}$ \\
\hline & $\begin{array}{l}\text { Concentrati } \\
\text { on } \\
\text { Ownership }\end{array}$ & Cnown & $\begin{array}{l}\text { The proportion that large shareholder who own } \\
\text { more than } 5 \% \text { in the firm }\end{array}$ & $\begin{array}{l}\text { Annual } \\
\text { Report }\end{array}$ \\
\hline \multicolumn{5}{|l|}{ Dependent } \\
\hline \multirow{3}{*}{$\begin{array}{l}\text { Firm } \\
\text { Performance } \\
\text { Measures }\end{array}$} & Tobin Q & TQ & $\begin{array}{l}\text { Book value of debt plus Market value of equity } \\
\text { divided by total assets }\end{array}$ & $\begin{array}{l}\text { Tadawul } \\
\text {.com.sa }\end{array}$ \\
\hline & $\begin{array}{l}\text { Return on } \\
\text { Asset } \\
\text { (ROA) }\end{array}$ & ROA & Operating Income divided by total Assets & $\begin{array}{l}\text { Tadawul } \\
\text {.com.sa }\end{array}$ \\
\hline & $\begin{array}{l}\text { Return on } \\
\text { Equity } \\
\text { (ROE) }\end{array}$ & ROE & Operating Income divided by total Equity & $\begin{array}{l}\text { Tadawul } \\
\text {.com.sa }\end{array}$ \\
\hline \multicolumn{5}{|l|}{ Control } \\
\hline \multirow[t]{2}{*}{$\begin{array}{c}\text { Financial } \\
\text { Characteristics }\end{array}$} & Firm Size & FZ & $\begin{array}{l}\text { Log of total asset will be used to present the value of } \\
\text { firm size }\end{array}$ & $\begin{array}{l}\text { Tadawul } \\
\text {.com.sa }\end{array}$ \\
\hline & Leverage & Lev & Total Non-current liabilities over Total assets & $\begin{array}{l}\text { Tadawul } \\
\text {.com.sa }\end{array}$ \\
\hline
\end{tabular}

\subsection{Limitations}

The results are subject to some limitations. Firstly, the data is based on facts and figures from only one year, i.e. 2013, as earlier records were unavailable. If a longer period were examined it may lead to more comprehensive and reliable findings. Secondly, the FP measures employed, i.e. ROA, ROE and Tobin's Q, to test the dependent variables, may not show the real values as the original figures for FP might be subject to management manipulation (Jones, 2011). Thus, the study does not show a full picture of all factors. Thirdly, the study only includes data from non-financial firms, so the findings do not represent the entire market. If financial industries were included, the findings may have differed. Fourthly, the research is concentrated only on the internal mechanisms of CG, entirely excluding external ones. This also hinders provision of the bigger picture. 


\section{Macrothink}

International Journal of Accounting and Financial Reporting ISSN 2162-3082 2016, Vol. 6, No. 2

In summary, this chapter presents the methods and procedures used to answer the central aim and research questions of the study and its limitations, which are to examine whether internal CG mechanisms have affected the performance of firms listed on the Saudi stock exchange since the implementation of Saudi CG code. Meanwhile, the next chapter will provide an empirical analysis of the study.

\section{Empirical Analysis}

\subsection{Introduction}

The previous two chapters discussed the relevant $\mathrm{CG}$ literature and explained the methodology and data that will be examined, to meet the study objectives. This chapter consists of three main sections, which will be analysed and discussed. Firstly, it presents the descriptive statistics of the data. Secondly, the correlation analysis is displayed and the third section focuses on the regression analysis and discussion the results, and its meaning.

\subsection{Descriptive Statistics}

Table 3: Descriptive Statistics

\begin{tabular}{|l|r|r|r|r|r|}
\hline \multicolumn{7}{|c|}{ Descriptive Statistics } \\
\hline & N & Minimum & Maximum & Mean & $\begin{array}{c}\text { Std. } \\
\text { Deviation }\end{array}$ \\
\hline Return on Assets \% & 118 & -60.42 & 45.00 & 6.72 & 11.06 \\
\hline Return on Equity \% & 118 & -20.70 & 115.00 & 12.43 & 15.85 \\
\hline Tobin Q & 118 & .69 & 6.59 & 1.94 & 1.12 \\
\hline Board Size & 118 & 4 & 13 & 8.50 & 1.63 \\
\hline Board Meeting & 118 & 1 & 17 & 5.53 & 2.44 \\
\hline Board Composition & 118 & 0 & 12 & 3.90 & 1.49 \\
\hline Chairman CEO Role Share & 118 & 0 & 1 & 0.13 & 0.34 \\
\hline Managerial Ownership\% & 118 & 0.00 & 98.00 & 17.66 & 20.93 \\
\hline $\begin{array}{l}\text { Concentration Ownership } \\
\%\end{array}$ & 118 & 5.00 & 98.00 & 36.17 & 23.95 \\
\hline $\begin{array}{l}\text { Firm Size (log of total } \\
\text { assets) }\end{array}$ & 118 & 4.62 & 8.53 & 6.35 & .72 \\
\hline Leverage \% & 118 & -45.30 & 326.53 & 36.35 & 62.20 \\
\hline Valid N (listwise) & 118 & & & & \\
\hline
\end{tabular}

The table above displays all the variables considered in this study. There are three dependent variables, used as FP measures for the 118 firms. Firstly, ROA (first accounting measure), which shows a minimum value of $-60.42 \%$ and a maximum of $45 \%$. The mean is $6.72 \%$ while the standard deviation is $11.06 \%$. With ROE (the second accounting measure), it is evident that the mean is $12.43 \%$, with a standard deviation of $15.85 \%$, while the minimum is $-20.70 \%$ with a maximum of $115 \%$. For the Tobin's Q (the market measure), the mean is $1.94 \%$ with a standard deviation of $1.12 \%$. The minimum value is $0.69 \%$, and the maximum value is $6.59 \%$. 


\section{Macrothink}

International Journal of Accounting and Financial Reporting

ISSN 2162-3082

2016, Vol. 6, No. 2

With regard to the independent variables, table 3 also displays information concerning the four board characteristics variables. The table reveals that the minimum board size of the listed companies is 4 , while 13 directors is the maximum, and the mean is 8.50 . This result was consistent with that of (Dogan and Smyth ,2002;Mak and Kusnadi, 2005;Ghabayen, 2012), who found a mean of 8.5 for board size. Jensen and Ruback (1983) suggested that a board size of not more than 8 or 9 members is legitimate for ensuring efficiency and effectiveness. Recent thoughts were built on smaller boards. Jensen (1993) and Lipton and Lorsch (1992) argued that large boards are less active making them easier for a CEO to monitor.

Table 3 show that the board meetings, have a minimum of 1 and maximum of 17 with a mean of 5.53 meeting annually. This means that the companies in Saudi Arabia hold a board meeting at least once each year, which complies with the Saudi CGC (Article 16, 1). This result is consistent with (Carcello, 2002) finding of a mean number of board meetings of 5.50 in the South-African market. However, the table also shows board composition involves a minimum of zero and a maximum of 12 independent members, with a mean of 3.9 for listed companies. This result is similar to Mousa and Desoky (2012a), who found a mean of 3.5 on the Bahrain Stock Exchange for 2012. The table also illustrates CEO duality is a maximum of 1 and a minimum of zero with a mean of $13 \%$. This result is consistent with findings reported by Goh et al. (2014).

Table 3 also shows the descriptive statistics for ownership characteristics. The concentrated ownership variable delivers a minimum of $5 \%$ and a maximum of $98 \%$, with a mean of $36 \%$. This result is similar to the findings of Soliman (2012), who found a mean of $30 \%$ of ownership concentration in Saudi market in 2011. However, managerial ownership, which refers to the percentage of shares owned by the group who manages the company, has a minimum of zero and a maximum of $98 \%$ with a mean of $17.66 \%$.

With regard to control variables, firm size returns a minimum of 4.62 and a maximum of 8.53 , with a standard deviation of $72 \%$. Saudi companies leverage has a minimum of $-45.30 \%$ and a maximum of $326.53 \%$, with a mean of $36.35 \%$, and a standard deviation of $62.2 \%$ which is a reasonable amount of leverage when compared to other markets; e.g. Bahrain (Desoky and Mousa, 2012b). 


\subsection{Regression Analysis and Discussion of results}

\subsubsection{Board characteristics and FP}

Table 4: Regression between board Characteristics and FP Measures

\begin{tabular}{|c|c|c|c|c|c|c|c|}
\hline \multirow{2}{*}{\multicolumn{2}{|c|}{ Variables }} & \multicolumn{2}{|c|}{$\begin{array}{l}\text { Market Performance } \\
\text { Tobin Q model } 1\end{array}$} & \multicolumn{2}{|c|}{$\begin{array}{l}\text { Accounting Performance } \\
\text { ROA model } 2\end{array}$} & \multicolumn{2}{|c|}{$\begin{array}{l}\text { Accounting Performance } \\
\text { ROE model } 3\end{array}$} \\
\hline & & $\begin{array}{c}\text { Without } \\
\text { firm size } \\
\text { and } \\
\text { leverage }\end{array}$ & $\begin{array}{l}\text { With firm } \\
\text { size and } \\
\text { leverage }\end{array}$ & $\begin{array}{l}\text { Without firm } \\
\text { size and } \\
\text { leverage }\end{array}$ & $\begin{array}{l}\text { With firm } \\
\text { size and } \\
\text { leverage }\end{array}$ & $\begin{array}{l}\text { Without firm } \\
\text { size and } \\
\text { leverage }\end{array}$ & $\begin{array}{l}\text { With firm } \\
\text { size and } \\
\text { leverage }\end{array}$ \\
\hline \multirow{2}{*}{$\begin{array}{c}\text { Board } \\
\text { Size }\end{array}$} & B & $-.178^{* * * *}$ & -.104 & .107 & -.043 & $2.132^{* * *}$ & $2.000^{* *}$ \\
\hline & Sig & $(.009)$ & $(.125)$ & $(.874)$ & $(.953)$ & $(.028)$ & $(.048)$ \\
\hline \multirow{2}{*}{\multicolumn{2}{|c|}{$\begin{array}{l}\text { Board } \\
\text { Meeting }\end{array}$}} & .006 & .014 & -.486 & -.514 & .436 & .353 \\
\hline & & $(.882)$ & $(.734)$ & $(.254)$ & $(.234)$ & $(.473)$ & $(.554)$ \\
\hline \multirow{2}{*}{\multicolumn{2}{|c|}{$\begin{array}{c}\text { Board } \\
\text { Compostion }\end{array}$}} & $1.922 \mathrm{E}-5$ & -.024 & -.419 & -.434 & -.541 & -.830 \\
\hline & & $(1.00)$ & $(.672)$ & $(.490)$ & $(.482)$ & $(.532)$ & $(.332)$ \\
\hline \multirow{2}{*}{\multicolumn{2}{|c|}{ CEO Dualtiy }} & -.404 & -.359 & $5.628^{\circ}$ & $5.625^{*}$ & 2.886 & 3.262 \\
\hline & & $(.194)$ & $(.220)$ & $(.072)$ & $(.074)$ & $(.515)$ & $(.452)$ \\
\hline \multirow{2}{*}{\multicolumn{2}{|c|}{ Firm Size }} & Nil & $-.420^{* *}$ & \multirow[t]{2}{*}{ Nill } & 1.159 & \multirow[t]{2}{*}{ Nil } & 2.376 \\
\hline & & & $(.016)$ & & $(.532)$ & & $(.356)$ \\
\hline \multirow{2}{*}{\multicolumn{2}{|c|}{ Leverage }} & Nil & -.002 & \multirow[t]{2}{*}{ Nil } & -.010 & \multirow[t]{2}{*}{ Nil } & $-.073^{* * *}$ \\
\hline & & & $(.204)$ & & $(.626)$ & & $(.011)$ \\
\hline \multirow{2}{*}{\multicolumn{2}{|c|}{ Constant }} & 3.439 & 5.618 & 9.457 & 3.941 & -6.276 & -16.028 \\
\hline & & $(.000)$ & $(.000)$ & $(.106)$ & $(.713)$ & $(.450)$ & $(.282)$ \\
\hline \multicolumn{2}{|c|}{$\begin{array}{c}\text { No. of } \\
\text { Observation }\end{array}$} & 118 & 118 & 118 & 118 & 118 & 118 \\
\hline \multicolumn{2}{|c|}{ R. Squared } & .074 & .193 & .041 & .045 & .050 & .108 \\
\hline \multicolumn{2}{|c|}{ F value } & 2.251 & 4.411 & 1.215 & 0.868 & 1.489 & 2.234 \\
\hline
\end{tabular}

Table 4 summarises the results from the first regression model examining the relationship between board characteristics (i.e. board size, board meeting, board composition and CEO duality) and FP (i.e. Tobin's Q, ROA and ROE). It presents two classes of results. First, the relationship between CG mechanisms and FP not including firm size and leverage variables, and secondly the relationship between the CG mechanisms and FP including firm size and leverage variables. Those results will be compared with the alternative hypotheses constructed based on previous studies reported in table 1 in the methodology chapter.

The first alternative hypothesis (H1) in table 1, identifies a relationship between board size and FP. In reference to model 1 , table 4 shows a negative and significant relationship between board size and Tobin's $\mathrm{Q}$, at the $1 \%$ significance level $(\mathrm{p}=0.009, \mathrm{~F}$ value $=2.251)$, and with $\mathrm{R}$ squared at 7.4\%, which means other elements affect the performance of Tobin's Q by $92.6 \%$. This negative relationship indicates that larger board size leads to a worse firm value. This may indicates that Saudi firms do not choose their board size ideally which result in lack of harmony, and leads to worse decision making that affect the FP negatively. The possible reason for this relationship is that firms with large board finds difficulties in controlling the board than smaller boards, which reflect in FP. However, when examining the model again, including the firm size and leverage variables, the result shows no relationship between board size and Tobin's Q. This means firm size and leverage have affected the previous findings, and therefore board size does not impact FP (Tobin's Q).

In reference to model 2, table 4 shows no relationship between board size and ROA. Even when including firm size and leverage in the model, the result still shows no relationship exists. The result is similar to that found by (Guest, 2009; Ghabayen, 2012), who examined 
Middle East non-financial firms and found no relationship between board size and FP (ROA).

In reference to model 3, table 4 shows board size have a positive and significant relationship, at a $5 \%$ significance level with $\mathrm{ROE}(\mathrm{p}=0.028, \mathrm{~F}$ value $=1.489)$ and an $\mathrm{R}$ squared value of $5 \%$, which means other elements affect the performance of ROE by $95 \%$. However, when considering other non-CG variables (i.e. firm size and leverage), board size is shown to have a positive relationship with $\mathrm{ROE}$ at a $5 \%$ significance level $(\mathrm{p}=0.048, \mathrm{~F}$ value $=2.234)$ and $\mathrm{R}$ squared level of 0.108 , which means that $10.8 \%$ of the variation in ROE is explained by all the regressors included. This positive relationship indicates a larger board leads to a better performance and vice versa.

The second alternative hypothesis in table 1, depicts a positive relationship between number of board meetings and FP. Table 4 shows there is no relationship between board meetings and FP (Tobin's Q, ROA and ROE). Even when including firm size and leverage in the model, the result shows no relationship between number of board meetings and FP measures. Table 3 shows Saudi firms have an average of 5.53 meetings, which has been described as a reasonable number of meetings (Johl et al., 2014). A possible explanation for the irrelevance of number of board meetings is that they may not meet the quality required by the CGC, and therefore their effectiveness is less. This result confirms Vefeas' (1999) argument that the number of times a boards meets does not reflect on performance, as meetings do not necessarily represent a full exchange of ideas between directors, making them meaningless. This result is consistent with (Elmehdi, 2007; Vefeas, 1999a; Carcello, 2002), who found no relationship between board meetings and FP.

The third alternative hypothesis presented in table 1 state there is a positive relationship between board composition and FP. The empirical result in table 4 shows no relationship between a board's composition and FP (Tobin's Q, ROA and ROE). Even when including firm size and leverage in the model the result still shows no relationship between the board composition and the FP measures. The reason why independent directors do not affect FP could be due to the full compliance with the CGC (Ghabyen, 2012). The Saudi CGC requires at least three independent directors or $33 \%$ independent directors on a board of directors. However, it was found (see table 3) that some large firms did not comply with the code (Cma.com, 2014). This empirical result is consistent with (Daily and Dalton, 1992; Brickley et al, 1997; Bhagat and Black 2002; Yermack, 1996) who found no relationship between board composition and FP, contradicting the work of Weiback (1988) and O'Connell and Cramer (2010), who found a positive relationship between board composition and FP. It could be concluded that board composition, does not affect FP. Therefore, H3 is rejected.

The fourth alternative hypothesis given in table 1, states there is a negative relationship between CEO duality and FP. The empirical results in table 4 show no relationship between CEO duality and FP (Tobin's Q and ROE). However, there is a significant and positive relationship between CEO duality and ROA at the $10 \%$ significant level $(\mathrm{p}=0.072$, F value $=1.215$ ) and an $\mathrm{R}$ squared of $4.5 \%$, which means there are other elements affecting the performance of ROA by $95.5 \%$. Even when including firm size and leverage in the model, the result shows the relationship between CEO duality and other FP measures are unchanged. 


\section{Mll Macrothink}

International Journal of Accounting and Financial Reporting ISSN 2162-3082 2016, Vol. 6, No. 2

This means that separating the Chairman's role from that of the CEO could lead to a slightly better FP. A possible reason for this relationship is that the Saudi CGC does not allow for duality in firms (Ezzine, 2012). Table 4 shows, roughly 13\% of firms failed to comply with the CGC, but the remaining $87 \%$ of the sampled companies did so, as apparent in the regression analysis. The result is consistent with the result reported by Uddin and Tsamenyi (2008) who examined Jordanian listed firms, and found FP improved when duality was separated. In addition, Sanda et al. (2003) examined firms listed in Nigeria and Kula (2005) and firms listed on the Turkish stock exchange, and found a positive relationship between FP and CEO duality. However, they claimed that the nature and effect of the duality relationship could differ from country to country depending on the CGC and culture. This contradicts reports by (Boyd, 1995; Kiel and Nicholson, 2003), who found a negative relationship between CEO duality and FP. These findings do not support H4. Therefore, the hypothesis is rejected.

With regard to firm size, table 4 shows that for model 1 there is a negative and significant relationship between firm size and Tobin's $Q$ at the 5\% significance level $(p=0.016, F$ value $=4.41$ ) and an $\mathrm{R}$ squared of $19.3 \%$. This relationship indicates smaller firms are more inventive and inspired to boost their value. One possible explanation is that as Saudi is an emerging market, investment opportunities coincide with economic growth, which attracts investors to invest in smaller firms and newly listed firms to maximise their wealth. The other possible explanation is that large firms have more power financially and greater resources than smaller firms, although they were less able to attract investors, as smaller firms grew their value more quickly than large firms. This finding is consistent with prior studies in the Saudi context (Hudaib and Haniffa, 2006; Aljaaidi, 2011). For models 2 and 3, there is no relationship between firm sizes and ROA or ROE, which is similar to the findings of Aljifri and Moustafa (2007).

With regard to leverage, table 4 shows models 1 and 2 have no relationship with Tobin's Q or ROA. However, model 3 shows a negative and significant relationship between leverage and ROE at the 5\% significance level $(\mathrm{p}=0.011, \mathrm{~F}$ value $=2.234)$ and $\mathrm{R}$ squared of $10.8 \%$. This relationship indicates firms with lower debts tend to perform better. One possible explanation for this is that firms with high leverage face a rise in their operational expenses to try to meet their financial obligation to pay a high rate of interest, which leads to results and cash problems, and reduces the earnings of the firm. Therefore, this affects FP negatively. This result is consistent with those reported by (Weir et al, 2002; Aljifri and Moustafa, 2007) and contradicts that of Mousa and Desoky (2012), who reported a positive relationship between leverage and FP. 


\section{MInstitute Macrothink $^{\text {Int }}$}

\subsubsection{Ownership Structure and FP}

Table 5: Regression between Ownership Characteristics and FP Measures

\begin{tabular}{|c|c|c|c|c|c|c|c|}
\hline \multirow{2}{*}{\multicolumn{2}{|c|}{ Variables }} & \multicolumn{2}{|c|}{$\begin{array}{c}\text { Market Performance } \\
\text { Tobin Q model } 1\end{array}$} & \multicolumn{2}{|c|}{$\begin{array}{c}\text { Accounting } \\
\text { Performance ROA } \\
\text { model } 2\end{array}$} & \multicolumn{2}{|c|}{$\begin{array}{c}\text { Accounting Performance } \\
\text { ROE model } 3\end{array}$} \\
\hline & & $\begin{array}{c}\text { Without } \\
\text { firm size } \\
\text { and } \\
\text { leverage }\end{array}$ & $\begin{array}{l}\text { With } \\
\text { firm size } \\
\text { and } \\
\text { leverage }\end{array}$ & $\begin{array}{l}\text { Without } \\
\text { firm size } \\
\text { and } \\
\text { leverage }\end{array}$ & $\begin{array}{l}\text { With firm } \\
\text { size and } \\
\text { leverage }\end{array}$ & $\begin{array}{l}\text { Without firm } \\
\text { size and } \\
\text { leverage }\end{array}$ & $\begin{array}{l}\text { With firm } \\
\text { size and } \\
\text { leverage }\end{array}$ \\
\hline \multirow{2}{*}{$\begin{array}{l}\text { Concentratio } \\
\text { n Ownership }\end{array}$} & B & -.005 & .007 & -.013 & -.031 & .079 & .085 \\
\hline & $\begin{array}{l}\mathrm{S} \\
\mathrm{i} \\
\mathrm{g}\end{array}$ & $(.317)$ & $(.153)$ & $(.773)$ & $(.564)$ & $(.224)$ & $(.253)$ \\
\hline \multirow{2}{*}{\multicolumn{2}{|c|}{$\begin{array}{l}\text { Managerial } \\
\text { Ownership }\end{array}$}} & $.010^{*}$ & .004 & $.108^{* * *}$ & $.117^{* *}$ & .108 & .080 \\
\hline & & $(.057)$ & $(.433)$ & $(.039)$ & $(.032)$ & $(.145)$ & $(.289)$ \\
\hline \multirow{2}{*}{\multicolumn{2}{|c|}{ Firm Size }} & \multirow[t]{2}{*}{ Nil } & $-.656^{* * *}$ & \multirow[t]{2}{*}{ Nill } & 1.008 & \multirow[t]{2}{*}{ Nil } & 2.600 \\
\hline & & & $(.000)$ & & $(.600)$ & & $(.331)$ \\
\hline \multirow{2}{*}{\multicolumn{2}{|c|}{ Leverage }} & \multirow[t]{2}{*}{ Nil } & -.001 & \multirow[t]{2}{*}{ Nil } & .002 & \multirow[t]{2}{*}{ Nil } & $-.072^{* * *}$ \\
\hline & & & $(.474)$ & & $(.938)$ & & $(.010)$ \\
\hline \multirow{2}{*}{\multicolumn{2}{|c|}{ Constant }} & 1.902 & 5.800 & 5.289 & -.689 & 7.678 & -5.936 \\
\hline & & $(.000)$ & $(.000)$ & $(.005)$ & $(.951)$ & $(.005)$ & $(.704)$ \\
\hline \multicolumn{2}{|c|}{$\begin{array}{c}\text { No. of } \\
\text { Observation }\end{array}$} & 118 & 118 & 118 & 118 & 118 & 118 \\
\hline \multicolumn{2}{|c|}{ R. Squared } & .032 & .192 & .038 & .042 & .046 & .102 \\
\hline \multicolumn{2}{|c|}{ F value } & 1.919 & 6.696 & 2.292 & 1.238 & 2.781 & 3.198 \\
\hline
\end{tabular}

The table above shows the results for the regression examining the relationship between ownership characteristics (i.e. Ownership concentration and Managerial ownership) and FP (i.e. Tobin's Q, ROA, ROE). The regression results will be compared with the alternative hypotheses constructed based on the previous studies in table 1, in the methodology chapter.

The fifth alternative hypothesis in table 1, states there is a positive relationship between managerial ownership and FP. In reference to model 3, table 5 shows no relationship between managerial ownership and ROE, but model 1 indicates a significant and positive relationship between managerial ownership and Tobin's $Q$ at the $10 \%$ significance level $(p=0.057, F$ value $=1.919$ ) and an $\mathrm{R}$ squared of $3.2 \%$, as the variation in Tobin's $\mathrm{Q}$ is explained by all regressors. However, when including firm size and leverage variables in the model, no relationship was found.

In model 2, table 5 shows a positive and significant relationship between managerial ownership and ROA at the 5\% significance level $(\mathrm{p}=0.039, \mathrm{~F}$ value $=2.292)$ and an $\mathrm{R}$ squared of .038, which means a $3.8 \%$ variation in ROA is explained by regressors. Even when including firm size and leverage in the model, the result remains significant and positive at the $5 \%$ significant level $(\mathrm{p}=0.032, \mathrm{~F}$ value $=1.238)$ and an $\mathrm{R}$ squared of $4.2 \%$. However, the above findings indicate higher managerial ownership is linked with higher firm value and performance. In other words, firms that have a large proportion of managerial ownership perform better than firms with a small proportion of managerial ownership do. The possible explanation for this relationship is that firms with higher managerial ownership have lower agency costs, which means that they save on some monitoring costs, and FP is expected to increase as claimed by (Morck et al., 1988; Soliman, 2012; Kumar and Singh, 2013). In this situation, the agency problem seems to be less influential in a condition where firms have a 


\section{Al Macrothink}

International Journal of Accounting and Financial Reporting

ISSN 2162-3082

2016, Vol. 6, No. 2

large proportion of managerial ownership, as the agency conflict is less (Jensen and Meckling, 1976).

The sixth alternative hypothesis in table 1 reports a positive relationship between concentration of ownership and FP. Table 5 shows no relationship between concentration and FP (i.e. Tobin's Q, ROA and ROE). Even when including firm size and leverage variables, no relationship was found. This means the concentration of ownership does not affect FP.

Table 5 shows a significant and negative relationship between firm size and Tobin's Q at the $1 \%$ significance level $(\mathrm{p}=0.000, \mathrm{~F}$ value $=1.919)$ and $\mathrm{R}$ squared of $19.2 \%$. However, there is a negative and significant relationship between leverage and ROE at the $1 \%$ significance level $(\mathrm{p}=0.010, \mathrm{~F}$ value $=3.198)$ and an $\mathrm{R}$ squared of $10.2 \%$. These results are similar to previous findings, reported in table 4.

\section{Conclusion}

\subsection{Conclusion}

In conclusion the study met its aim and objectives by examining the relationship between internal CG mechanisms and FP. The methodology employed was to create an OLS model of multiple regressions, taking CG mechanisms and company's respective performances as independent and dependent variables respectively for a sample of 118 non-financial Saudi firms in 2014. The study concludes that three of the CG mechanisms, i.e. board size, CEO duality and managerial ownership as well as firm size and leverage variables, had an impact on FP in Saudi Arabia. Whereas, the other three internal mechanisms, board meeting, board composition, and concentration of ownership were found to have no impact on FP. It could be concluded that the insignificant impact of $\mathrm{CG}$ variables was due to lack of compliance with CGC, as discussed in the analysis above. For future research it is suggested to take into account that both internal and external mechanisms (i.e. regulations) associated with CG should be examined in mixed sample of the financial and non-financial industries together, to examine which industry is most affected by the CG code.

\section{References}

Abu-Tapanjeh, A., 2009. Corporate Governance from the Islamic Perspective: A Comparative Analysis with OECD Principles. Journal of Critical Perspectives on Accounting,20(5), pp.556-567.

Adams, R. and Mehran, H., 2003. Is Corporate Governance Different for Bank Holding Companies. Economic Policy Review, 9(1), pp.123-142.

Aduda, J., Chogii, R. and Magutu, P.,2013. An empirical test of competing corporate governance theories on the performance of firms listed at the Nairobi Securities Exchange. European Scientific Journal,9(13).

Agrawal, A. and Chadha, S., 2005. Corporate Governance and Accounting Scandals. Journal of law and economics, 48(2), pp.371-406. 
Albrecht, W., Albrecht, C. and Albrecht, C., 2004. Fraud and corporate executives: Agency, stewardship and broken trust. Journal of Forensic Accounting, 5(1), pp.109-130.

Al Farooque, O., van Zijl, T., Dunstan, K. and Karim, A.,2010. Co-deterministic Relationship between Ownership Concentration and Corporate Performance: Evidence from an Emerging Economy. Accounting research journal, 23(2), pp.172-189.

Al-Moataz, E. and Hussainey, K., 2012.Determinants of Corporate Governance Disclosure in Saudi Companies". Journal of Economics and Management. 48(1), pp.22-40.

Al-Janadi, Y., Rahman, R. and Omar, N., 2013. Corporate Governance Mechanisms and Voluntary Disclosure in Saudi Arabia. Research Journal of Finance and Accounting, 4(4), pp.25-35.

Aljifri, K., and Moustafa, M., 2007. The impact of corporate governance mechanisms on the performance of UAE firms: an empirical analysis. Journal of Economic and Administrative Sciences, 23(2), 71-93.

Alkhudairy, K., 2008. Stock Prices and the Predictive Power of Macroeconomic Variables The Case of the Saudi Stock Market. 1st ed. Colorado State: Colorado State University.

Al-Khouri, R., 2006. "Corporate governance and firm value in emerging markets: The case of Jordan", Journal of Transnational Management, Vol. 12, 25 - 49.

Almatari, Y., AlSwidi, A. and Bt Fadzil, F., 2012. Corporate Governance and Performance of Saudi Arabia Listed Companies. British Journal of Arts and Social Sciences, 9(1), pp.1-33.

Alzharani, A., Ahmad, M. and Aljaaidi, K., 2011. An Empirical Investigation of Factors Associated with Firm Pperformance: Evidence From Kingdom of Saudi Arabia. International Conference on E-business, Management and Economics, 25(2), pp.25-37.

Azam, M., Usmani, S., \& Abassi, Z., 2011. The Impact of Corporate Governance on Firm's Performance: Evidence from Oil and Gas Sector of Pakistan. Australian Journal of Basic and Applied Science, 5(12), 2978-2983.

Bai, C., Liu, Q., Lu, J., Song, F. and Zhang, J.,2004. Corporate Governance and Firm Valuations in China. [Online] Papers.ssrn.com. Available at: http://papers.ssrn.com/sol3/papers.cfm?abstract_id=361660 [Accessed 17 Jul. 2014].

Bartholomeusz, S. and Tanewski, G.,2006.The Relationship Between Family Firms and Corporate Governance. Journal of Small Business Management, 44(2), pp.245--267.

Berle, A. A. and G. C. Means., 1932. The Modern Corporation and Private Property. Published by Harcourt, Brace and World, New York.

Becht, F., Macro, G., \& Patrick, B.,2002. Corporate Governance and Control. Working Paper no. 9371.National Bureau of Economic Research, Cambridge, MA.1-128.

Becht, M., Bolton, P. and Röell, A.,2005. Corporate Governance and Control. [Online] 


\section{Ml Macrothink}

International Journal of Accounting and Financial Reporting ISSN 2162-3082 2016, Vol. 6, No. 2

Papers.ssrn.com. Available at: http://papers.ssrn.com/sol3/papers.cfm?abstract_id=343461 [Accessed 17 Jul. 2014].

Bennedsen, M., Kongsted, H. and Nielsen, K.,2008. The Causal Effect of Board Size in the Performance of Small and Medium-sized Firms. Journal of Banking \& Finance, 32(6), pp.1098-1109.

Bergolf, E and Perotti E., 1994. The Governance Structure of the Japanese Financial Kererus. Journal of Financial Economics. 36.pp 259-284.

Biais, B and Perotti, E., 2002. Machiavellian Privatization. American Economic Review. 92. pp249-258.

Bhagat, S and Black, B., 2002. "The non correlation between Board Independence and LongTerm Firm performance”, Journal of Corporation Law, vol.27, No.2,pp 231-273.

Blair, M.,1996. Ownership and Control: Rethinking Corporate Governance for the Twentyfirst Century. Published by Brookings Institution. Washington.

Bonn, I., Yoshikawa, T., and Phan, H.,2004. Effects of Board Structure on Firm Performance: A Comparison between Japan and Australia. Asian Business \& Management Journal,No.3, pp105-125.

Bolbol, A., Fatherldin, A. \& Omran, M.,2003. Ownership Structure, Firm Performance, and Corporate Governance: Evidence from Selected Arab Countries. The Economic Research Journal, No. 15 (3).pp. 311-322.

Bowen, R., Rajgopal, S. and Venkatachalam, M.,2008. Accounting Discretion, Corporate Governance, and Firm Performance. Contemporary Accounting Research Journal.No.25(2), pp351-405.

Boyd, B.,1995. CEO Duality and Firm Performance: A Contingency Model. Strategic Management Journal. No.16(4) pp301-312.

Brickley, J. A, Coles, J. L \& Terry, R. L.,1997. Outside Directors and the Adoption of Poison Pills. Journal of Financial Economics, No.35, 371-90.

Brickley, J. A. \& C.M. James., 1997. The Takeover Market, Corporate Board Composition, and Ownership Structure: The Case of Banking. Journal of Law and Economics, 30, 161-181.

Buchholtz, J., Young, M and Powell, J.,1998. Are Board members Pawn or watchdog? The link between CEO Pay and Firm Performance. Journal Group and Organisation Management. 23(1), p6-26.

Carver, J. and Oliver, C., 2002. Corporate Boards that Create Value. 1st ed. Published by Jossey-Bass. San Francisco.

Carcello, J. V., Hermanson, D. R., Neal, T. L., and Riley, R. A., 2002. Board Characteristics and Audit Fees. Contemporary Accounting Research, 19: 2. pp.365-384.

Chaghadari, M.,2011. Corporate Governance and Firm Performance. International 


\section{Macrothink}

International Journal of Accounting and Financial Reporting

ISSN 2162-3082 2016, Vol. 6, No. 2

Conference on Sociality and Economics Development, 10(2), pp.55-85.

Cheng, S., Evans, J. and Nagarajan, N.,2008. Board size and Firm Performance: the moderating effects of the market for corporate control. Review of Quantitative Finance and Accounting, 31(2), pp.121--145.

Chen, I., 2013. Financial Crisis and the Dynamics of Corporate Governance: Evidence from Taiwan's listed Firms. International Review of Economics and Finance, 32, pp.3-28.

Chen, Z., Cheung, Y., Stouraitis, A. and Wong, A., 2005. Ownership Concentration, Firm Performance, and Dividend Policy in Hong Kong. Pacific-Basin Finance Journal,13(4), pp.431-449.

Choo, C., 2008. Organizational Disasters: Why they Happen and How they May be Prevented. Management Decision Journal, 46(1), pp.32--45.

CMA.,2013.Corporate Governance Regulation in Saudi Arabia. [Online] CMA. Available at: http://www.cma.org.sa/En/Documents/CORPORATE\%20GOVERNANCE\%20REGULATIO NS-2011.pdf [Accessed 1 Jul. 2014].

Claessens, S. and Fan, J. (2002). Corporate Governance in Asia: A survey. International Review of Finance, 3(2), pp.71-103.

Clarke, T.,2004. Theories of Corporate Governance: The Philosophical Foundation of Corporate Governance. Rout Ledge Taylor\& Francis Group: London.

Coombes, P. and Watson, M.,2001."Corporate reform in the developing world". McKinsey Quarterly special edn., no. 4, 89-93.

Daily, C and Dalton, D and Cancella, A. ,2003. Corporate Governance: Decades of Dialogue and Data. Academy of Management Review. 28(3). P371-382.

Dalton, D., Daily, C., Johnson, J. and Ellstrand, A.,1998. Number of Directors and Financial Performance: A Meta-analysis. Academy of Management Journal, 42(6),pp.674-686.

Daily, D., Dalton, C.,1998.Meta-Analytic Reviews of Board Composition, Leadership Structure, and Financial Performance. Strategic Management Journal, 19(3),pp.269-290.

Davis, J., Schoorman, F. and Donaldson, L.,1997.Toward a Stewardship Theory of Management. Academy of Management review, 22(1),pp.20-47.

Darman, G.,2004.Corporate Governance Worldwide | ICC Store. [online] Store.iccwbo.org. Available at: http://store.iccwbo.org/corporate-governance-worldwide [Accessed $22 \mathrm{Jul}$. 2014].

Davidson WN, Pilger T, Szakmary A., 1998. "Golden Parachutes, Board and Committee Composition and Shareholder Wealth”. The Financial Review,pp.17-32.

Demsetz H., Lehn K., 1985. The Structure of Corporate Ownership: Causes and Consequences, Journal of Political Economy, 93(6), 1155-1177. 


\section{Macrothink}

International Journal of Accounting and Financial Reporting ISSN 2162-3082 2016, Vol. 6, No. 2

Demsetz, H. and Villalonga, B., 2001. Ownership Structure and Corporate Performance.

[online] Papers.ssrn.com. Available at: http://papers.ssrn.com/sol3/papers.cfm?abstract_id=266101 [Accessed 22 Aug. 2014].

Dorrenbacher, C.,2011. Politics and Power in the Multinational Corporation: The role of Institutions, Interests and Identities. Cambridge University Press.

Drennan, L.,2004. Ethics, Governance and Risk Management: Lessons from Mirror Group Newspapers and Barings Bank. Journal of Business Ethics, 52(3), pp.257--266.

Dey, A.,2008. Corporate Governance and Agency Conflicts. Journal of Accounting Research, 46(5), pp.1143--1181.

Eisenberg, T., Sundgren, S., and Wells, T.,1998. Larger Board Size and Decreasing Firm Value in Small Firms. Journal of Financial Economics, 48,pp35-54.

Elmehdi, I., 2007.Empirical Evidence on Corporate Governance and Corporate Performance in Tunisia. Corporate Governance: An International Review, 15(6), pp.1429-1441.

Ezzine, H.,2012.A Cross Saudi Firm Analysis of the Impact of Corporate Governance on the Stock Price Performance During the Recent Financial Crisis. European Journal of Economics, Finance and Administrative Sciences 43 (1), pp 37-154.

Fazlzadeh, A., Hendi, A. and Mahboubi, K., 2011.The Examination of the Effect of Ownership Structure on Firm Performance in Listed Firms of Tehran Stock Exchange Based on the Type of the Industry. International Journal of Business and Management, 6(3), pp.249-260.

Faleye, O., 2011. CEO Directors, Executive Incentives, and Corporate Strategic Initiatives. Journal of Financial Research, 34(2),pp.241-277.

Fallatah, Y. and Dickins, D., 2012. Corporate Governance and Firm Performance and Value in Saudi Arabia. African Journal of Business Management, 6(36), pp.10025--10034.

Fama, E.F.,1980. Agency Problems and the Theory of the Firm. Journal of Political Economy, 88 (2): pp.288-307.

Fama, E. and Jensen, M.,1983. Agency Problems and Residual Claims. Journal of law and Economics, pp.327--349.

Fan, P.,2004. Review of Literature \&Empirical Research: Is Board Diversity important for Corporate Governance and firm value?. Published by Monetary Authority of Singapore Staff papers. 35 .

Fich, E. M., and Shivdasani, A.,2006. Are Busy Boards Effective Monitors. Journal of Finance 51:2. pp. 689-724.

Finkelstein, S. and D'aveni, R.,1994. CEO Duality as a Double-edged Sword: How Boards of Directors Balance Entrenchment Avoidance and Unity of Command. Academy of Management Journal, 37(5), pp.1079--1108. 


\section{Mll Macrothink}

International Journal of Accounting and Financial Reporting ISSN 2162-3082 2016, Vol. 6, No. 2

Freeman, R., Wicks, A. and Parmar, B., 2004. Stakeholder Theory and "the Corporate Objective Revisited". Organization Science Journal, 15(3), pp.364--369.

Gee publishing LTD., 1998.Committees on Corporate Governance. [Online] ECGI. Available at: http://www.ecgi.org/codes/documents/hampel.pdf [Accessed 2 Aug. 2014].

Ghabayen, M. A.,2012. Board Characteristics and Firm Performance: Case of Saudi Arabia. International Journal of Accounting and Financial Reporting, 2 (2), pp. 131-168.

Ghoshal, S.,2005. Bad Management Theories are Destroying Good Management Practices. Academy of Management Learning and Education Journal, 4(1), pp.75--91.

Gephart, R., 2004. Qualitative Research. Academy of Management Journal, 47(4), pp.454-462.

Giddings, L., 2006. Mixed-methods Research Positivism Dressed in Drag. Journal of research in nursing, No.11(3), pp.195-203.

Gillan, S. and Starks, L., 2000. Corporate Governance Proposals and Shareholder Activism: The Role of Institutional Investors. Journal of financial Economics, 57(2), pp.275-305.

Godard, L and Shatt, A., 2004.Governance and Performance Revisited ECGI, Finance Working Paper No. 28/2003; EFA Annual Conference Paper No. 252.

Goh, C., Rasli, A. and Gomes, S., 2014. CEO Duality, Board Independence, Corporate Governance and Firm Performance in Family Firms: Evidence from the Manufacturing Industry in Malaysia. Asian Business \& Management, 4(9), pp.30-45.

Gomes, R.,2006. Stakeholder Management in the Local Government Decision-making area: Evidences from a Triangulation Study with the English Local Government. BAR-Brazilian Administration Review, 3(1), pp.46--63.

Goergen, M., Brewster, C. and Wood, G.,2010. Corporate Governance: Non-equity Stakeholders, Corporate Governance: A Synthesis of Theory, Research, and Practice, 2 (9),pp.469-495.

Greener, I.,2006. Nick Leeson and the Collapse of Barings Bank: Socio-Technical Networks and the 'Rogue Trader'. Organization Research Journal, 13(3), pp.421--441.

Grosfeld, I.,2006. Ownership Concentration, Uncertainty, and Firm Performance: Evidence from an Emerging Market. University of Michigan in its series William Davidson institute working papers series, (834).

Guest, P.,2009. The Impact of Board Size on Firm Performance: Evidence from the UK. The European Journal of Finance, 15(4), pp.385--404.

Hahn, P. and Lasfer, M.,2011. Vanishing Board Meetings: Has Governance Doomed the Board Meeting. Cass Business School Research Paper. London.

Hassan, M., 2009. UAE Corporations-specific Characteristics and Level of Risk Disclosure. Managerial Auditing Journal, 24(7), pp.668--687. 


\section{Macrothink}

International Journal of Accounting and Financial Reporting ISSN 2162-3082

Haniffa, R., and Hudaib, M.,2006. Corporate governance structure and performance of Malaysian listed companies. Journal of Business Finance \& Accounting, 33, 1034-1062.

Hart, O.,1995. Corporate Governance, Some Theories and Application. Published by The Economic Journal. 105,pp687-689.

Hermalin, B. E., and Weisbach, M. S., 2003. Boards of Directors as an Endogenously Determined Institution: A Survey of the Economic Literature. Economic Policy Review Federal Reserve Bank of New York, 9, (7) 26.

Holderness, C. \& Sheehan, D.,1988. The Role of Majority Shareholders in Publicly Held Corporations: An Exploratory Analysis. Journal of Financial Economics, No.20,pp.317-346.

Ho, K.,2005. Reforming Corporate Governance in Southeast Asia. 1st ed. Institute of Southeast Asian Studies Journal. Singapore

Hussainey, K. and Al-Nodel, A., 2009. Corporate Governance and Online Reporting by Saudi Listed Companies. Journal of Research in Accounting in Emergi ng Economies, 8, pp.39--64.

Jaafar, A. and El-Shawa, M.,2009. Ownership Concentration, Board Characteristics and Performance: Evidence from Jordan. Research in accounting in emerging economies Journal, 9, pp.73--95.

Jackling, B. and Johl, S., 2009. Board Structure and Firm Performance: Evidence from India's top companies. Corporate Governance: An International Review, 17(4), pp.492--509.

Jensen M.C. and Meckling W.,1976. Theory of the Firm: Managerial Behaviour, Agency Costs and Ownership Structure. Journal of Financial Economics. 3 (4),pp. 305-360.

Jensen, M. C.,1993. The Modern Industrial Revolution, Exit and the Failure of Internal Control Systems. Journal of Finance, 48(2),pp.831-880.

Johl, S., Kaur, S. and Cooper, B.,2014. Board Characteristics and Firm Performance: Evidence from Malaysian Public Listed Firms. Journal of Economics, 3(2).pp. 55-70

Jones, M.,2011. Creative Accounting, Fraud and International Accounting Scandals. 1st ed. John Wiley \& Sons, England.

Judge, W., Naoumova, I. and Koutzevol, N.,2003. Corporate Governance and Firm Performance in Russia: an Empirical study. Journal of World Business, 38(4), pp.385--396.

Kajola, S., 2008. Corporate Governance and Firm Performance: The Case of Nigerian Listed Firms. European Journal of Economics, Finance and Administrative Sciences, 14(14), pp.16-28 .

Kaplan, S.,1989.The Effect of Management Buyouts on Operation Performance and Value. Journal of Financial Economics. 24. pp.218-254.

Karaca, S. S., and Eksi, I. H.,2012. The Relationship between Ownership Structure and Firm Performance: An Empirical Analysis over Istanbul Stock Exchange (ISE) listed companies. International Business Research, 5(1), pp.172-181. 


\section{Macrothink}

International Journal of Accounting and Financial Reporting ISSN 2162-3082 2016, Vol. 6, No. 2

Keasy, K. and Wright. M.,1997.Corporate Governance-Responsibilities, Risk and Remuneration. John Wiley and Sons, New York.

Khan, A and Awan, S., 2012. Effect of Board Composition on Firm's Performance: A Case of Pakistani listed Companies. Journal Of Contemporary Research In Business, 3, pp. 853- 863.

Khan, K., Nemati, A. R., \& Iftikhar, M.,2012. Impact of Corporate Governance on Firm Performance: Evidence from the Tobacco Industry of Pakistan. International Research Journal of Finance and Economics, 61, pp.7-14.

Kiel, G. and Nicholson, G.,2003. Board Composition and Corporate Performance: How the Australian Experience Informs Contrasting Theories of Corporate Governance. Corporate Governance: An International Review, 11(3), pp.189--205.

Klein, P., Suchard, J., and Jason, Z.,2005. Corporate Governance Cost of Capital and Performance: Evidence from Australian Firms. Journal of Finance, 6,pp.1-28.

Kula, V.,2001. The Impact of the Roles, Structure and Process of Boards on Firm Performance: Evidence from Turkey. Corporate Governance: An International Review, 13(2), pp.265--276.

Kumar, N. and Singh, J.,2013. Effect of Board Size and Promoter Ownership on Firm Value: Some Empirical Findings from India. Corporate Governance, 13(1), pp.88--98.

Kyereboah-Coleman, A. and Biekpe, N.,2006. The Link between Corporate Governance and Performance of the Non-traditional Export Sector: Evidence from Ghana. Corporate Governance: The International Journal of Effective Board Performance, 6(5), pp.609--623.

La Porta, R., Lopez-de-Silanes, F., Shleifer, A. and Vishny, R., 2000. Investor Protection and Corporate Governance. Journal of financial economics, 58(1), pp.3--27.

Lam, T. and Lee, S.,2008. CEO Duality and Firm Performance: Evidence from Hong Kong. Corporate Governance, 8(3), pp.299--316.

Lasfer, M.A., 2004. On the Monitoring Role of the Board of Directors: The Case of the Adoption of Cadbury Recommendations in the UK. Advances in Financial Economics, 9, pp. 287-326.

Lehuede, H., Kirkpatrick, G. and Teichmann, D., 2012.Corporate Governance Lessons from the Financial Crisis. [Online] Papers.ssrn.com. Available at: http://papers.ssrn.com/sol3/papers.cfm?abstract_id=2393978 [Accessed 24 Aug. 2014].

Letza, S., Sun, X. and Kirkbride, J.,2004. Shareholding Versus Stakeholding: A Critical Review of Corporate Governance. Corporate Governance: An International Review, 12(3), pp.242--262.

Leuz., C., Nanda, D. and Wysocki, P.,2003. Earning Management and Investor Protection: An International Comparison. Journal of Financial Economics 69,pp.505-527.

Levine, R.,1999. Financial Development and Economic Growth: Views and Agenda. World 
Bank policy research working paper, (1678).

Liang, C., Lin, Y. and Huang, T.,2011. Does Endogenously Determined Ownership Matter on Performance Dynamic: Evidence from the Emerging Taiwan market. Emerging Markets Finance and Trade, 47(6), pp.120--133.

Lipton, M. and Lorsch, J., 1992. A Modest Proposal for an Improved Corporate Governance. The Business Lawyer Journal, 48(1),pp.59-77.

Li, W., Chen, C. and French, J.,2012. The relationship between liquidity, corporate governance, and firm valuation: Evidence from Russia. Emerging Markets Review, 13(4), pp.465--477.

Loderer, C., \&Peyer, U.,2002. Board Overlap, Seat Accumulation and Share Prices. European Financial Management, No.8,pp.165-92.

Lucy, T.,2002. Quantitative Techniques. $6^{\text {th }}$ Edition, DPP Publishing, London.

Mak, Y.T. and Kusnadi.Y.,2005. Size Really Matters: Further Evidence on the Negative Relationship between Board Size and Firm Value. Pacific-Basin Finance Journal, 13, pp.301-318.

Mallin, C.,2010. Corporate Governance. Third edn. Oxford University Press.

Mandaci, P. and Gumus, G.,2010. Ownership Concentration, Managerial Ownership and Firm Performance: Evidence from Turkey. South East European Journal of Economics and Business, 5(1), pp.57--66.

Mangena, M., and Tauringana, V.,2008. Corporate Boards, Ownership Structure and Firm Performance in an Environment of Severe Political and Economic Uncertainty". Published by British Accounting Association Conference, April 2008, Blackpool.

Mead, L., Mead, L. and Bampton, K.,2009. CIMA Certificate in Business Accounting. 1st edn. Elsevier Journal. Oxford.

Megginson, W. and Netter, J.,2001. From State to Market: A Survey of Empirical Studies on Privatization. Journal of economic literature, pp.321--389.

Mehran, H., Morrison, A., and Shapiro, J., 2011. Corporate Governance and Banks: What Have We Learned from the Financial Crisis?.Federal Reserve Bank of New York. Staff Reports, pp. 485-502.

Morck, R., Shleifer, A. and Vishny, R.,1988. Management Ownership and Market Valuation: An Empirical Analysis. Journal of Financial Economics, 20,pp.293-315.

Mousa, G. A. and Desoky, A. M.,2012a. The Association between Internal Governance Mechanisms and Corporate Value: Evidence from Bahrain. Asian Academy of Management Journal of Accounting and Finance, pp.1-18.

Mousa, G., Desoky, A. and Sanusi, Z.,2012b. Do Board Ownership Characteristics Affect on Firm Performance: Evidence from Egypt. Global Advanced Research Journal of Economics, 
Accounting and Finance, 1(2), pp.15-32.

Murya, H.,2010.The Effectiveness of Corporate Governance and External Audit on Constraint Earning Management Practise in the UK. 1st ed. [e-Thesis] Durham: University of Durham, pp.118-133. Available at: http://etheses.dur.ac.uk/448/1/FINAL_WHOLE_PHD_pdf.pdf?DDD2+[Accessed 24 Aug. 2014].

Naoum, S.,2013. Dissertation Research and Writing for Construction Students. 1st edn. Published by Rutledge. New York.

Nazlianum, M. G.,2010. Ownership Structure, Corporate Governance and Corporate Performance in Malaysia. International Journal of Commerce and Management, 20(2), pp.109-119.

Ntim, C. G.,2009. Internal Corporate Governance and Firm Financial Performance: Evidence from South-African listed Firms. PhD thesis, University of Glasgow.

Ntim, C. and Oseit, K.,2011. The Impact of Corporate Board Meetings on Corporate Performance in South-Africa. African Review of Economics and Finance, 2(2), pp.83--103.

Nuryanah, S., \& Islam, S. M. N.,2011. Corporate Governance and Performance : Evidence from an Emerging Market. Malaysian Accounting Review, 10(1), pp.17-42

O'Connell, V. and Cramer, N.,2010.The Relationship between Firms Performance and Board Characteristics in Ireland. European Management Journal, 28(5), pp.387--399.

Obiyo, O. C., \& Lenee, L. T.,2011.Corporate Governance and firm's performance in Nigeria. Published by IJEMR, 1(4), pp. 1-12.

Ogbechie, C., Koufopoulos, D. and Argyropoulou, M.,2009. Board Characteristics and Involvement in Strategic Decision-making: The Nigerian Perspective. Management Research News, 32(2), pp.169--184.

Ongore, V. and K'Obonyo, P.,2011. Effects of Selected Corporate Governance Characteristics on Firm Performance: Empirical Evidence from Kenya. International Journal of Economics and Financial Issues, 1(3), pp.99--122.

Omran, M.,2009. Post-privatization Corporate Governance and Firm Performance: The Role of Private Ownership Concentration, Identity and Board Composition. Journal of comparative Economics, 37(4), pp.658--673.

Peng, W. (2008). Global Strategy. Second edition. Published by Cengage Learning. USA.

Pfeffer, J.,1972. Size and Composition of Corporate Board of Directors: The Organization and its Environment, Administrative Science Quarterly Journal, 17,pp. 218-29.

Plessis, J., Haragovan, A., and Bagaric, M.,2011.Principles of Contemporary Corporate Governance. Published Cambridge University Press. New York.

Prasad, K.,2006. Corporate Governance. Published by PHI Learning Pvt. Ltd. India. 


\section{Macrothink}

International Journal of Accounting and Financial Reporting

ISSN 2162-3082

2016, Vol. 6, No. 2

Ramady, M.,2010. “The Saudi Arabian Economy: Policies, Achievements, and Challenges Second edition. Published by Springer Science. London

Ramdani, D. and Witteloostuijn, A.,2010. The Impact of Board Independence and CEO Duality on Firm Performance: a Quantile Regression Analysis for Indonesia, Malaysia, South Korea and Thailand. British Journal of Management, 21(3), pp.607--627.

Rezaee, Z., 2009.Corporate Governance and ethics. Published by John Wiley. Hoboken, NJ.

Roberts, J., McNulty, T., and Stiles,P., 2005. Beyond Agency Conception of the Work of nonExecutive Director: Creating Accountability in the Boardroom. British Journal of Management. 16(1), pp.5-26.

Samaha, K., Dahawy, K., Hussainey, K. and Stapleton, P.2012. The Extent of Corporate Governance Disclosure and its Determinants in a Developing Market: The Case of Egypt. Advances in Accounting, 28(1), pp.168-178.

Samba Financial Group., 2009. The Saudi Stock Market: Structural Issues, Recent Performance and Outlook. [Online] Available at: http://www.samba.com/GblDocs/Saudi_Stock_Market_Eng.pdf. [Accessed: 26 Jan 2013].

Saunders, M.N.K., Lewis, P., Thornhill, A.,2009. Research Methods for Business Students. 4th Edition. Published by Financial Times/Prentice Hall. Harlow.

Sanda, A., Mikailu, A. S., and Garba, T.,2005. Corporate Governance Mechanisms and Firm Financial Performance in Nigeria. African Economic Research Consortium research Paper,77(5),pp. 1-47.

Siala, F., Adjaoud, F., \& Mamoghli, C.,2009.The Combined Effect of External Auditor Reputation and Internal Corporate Governance on Performance. Journal of Academy of Business and Economics, 9(2), pp.16-29.

Schilling, M.,2000. Decades Ahead of Her Time: Advancing Stakeholder Theory Through the idea of Mary Parker Follett. Journal of Management Hisort. 6(5), pp.224-242.

Shapiro, S.,2005. Agency Theory. Annual Review of Sociology, 3(31), pp.263-284.

Shleifer, A. and Vishny, R.,1988. Value maximization and the acquisition process. The Journal of Economic Perspectives, 2(1), pp.7--20.

Shleifer, A. and Vishny, R.,1997. A Survey of Corporate Governance. The Journal of Finance, 52(2), pp.737--783.

Shleifer, A., and Vishny, R., 2000. Investor Protection and Corporation Valuation. The Journal of Finance,57(3), pp.1147-1170.

Singh, D. A., \& Gaur, A. S.,2009. Business Group Affiliation, Firm Governance, and Firm Performance: Evidence from China and India. Corporate Governance: An International Review, 17(4), pp.411-425.

Short, H. and Keasey, K.,1999. Managerial Ownership and the Performance of Firms: 


\section{Macrothink}

International Journal of Accounting and Financial Reporting ISSN 2162-3082 2016, Vol. 6, No. 2

Evidence from the UK. Journal of corporate finance, 5(1), pp.79--101.

Shukeri, S., Shin, O. and Shaari, M.,2012. Does Board of Director's Characteristics Affect Firm Performance: Evidence from Malaysian Public Listed Companies. International Business Research, 5(9), pp.120-133.

Smith, A.,1990. Corporate Ownership Structure and Performance the Case of Management Buyouts. Journal of Finance Economics. 27,pp.144-165.

Solomon, J.,2010. Corporate Governance and Accountability. Third edition. Published by John Wiley \& Sons Ltd. Chichester, West Sussex.

Sonnenfeld, J. A., 2002. What Makes Great Boards. Harvard Business Review. 80(9). pp.106113.

Sternberg, E.,2004. Corporate Governance. 1st edn. Published by the Institute of Economic Affairs. London.

Stulz, R.,1999.Globalization of Equity Markets and the Cost of Capital. [Online] Papers.ssrn.com. Available at: http://papers.ssrn.com/sol3/papers.cfm?abstract_id=153669 [Accessed 19 Jul. 2014].

Soliman, M.,2012. Ownership Concentration and Firm Financial Performance Evidence from Saudi Arabia. [Online] Papers.ssrn.com. Available at: http://papers.ssrn.com/sol3/papers.cfm?abstract_id=1492879 [Accessed 24 Aug. 2014].

Sundaram, A. and Inkpen, A., 2004. Stakeholder Theory and "The Corporate Objective Revisited": A reply. Organization Science Journal, 15(3), pp.370--371.

Tadawul.com.sa., 2006. Publications. [Online] Available at: http://www.tadawul.com.sa/static/pages/en/Publication/publications.html [Accessed: 5 Feb 2013].

Thomas, K., 2005. Conflict and Conflict Management: Reflections and Update. Journal of Organizational Behavior, 13(3), pp.265--274.

Thomas, B., Deshmukh, M. and Kumar, P.,2005.High Performing Organisations. Published by Tata McGraw-Hill Education. India.

Uadiale, O.,2010.The Impact of Board Structure on Corporate Financial Performance in Nigeria. International Journal of Business and Management, 5(10), pp.155.

Uddin, S. and Tsamenyi,M., 2008.Corporate Governance in Less Developed and EmergingEconomies. 1edn. Published by JAI press. London.

Vefeas, N., 1999. Board Meeting Frequency and Firm Performance. Journal of Financial Economics, 53(2), pp. 113-142.

Vefeas, N., 1999b.The Nature of Board Nominating Committees and Their Roles in Corporate Governance. Journal of Business Finance \& Accounting, 26(2). pp199-225. 


\section{Macrothink}

International Journal of Accounting and Financial Reporting

ISSN 2162-3082

2016, Vol. 6, No. 2

Vincent, P.,2008. Saudi Arabia. 1st ed. Published by Taylor \& Francis. London.

Wahla, S., Hussain, Z. and Saha, R.,2012. Impact of Ownership Structure on Firm Performance: Evidence from Non-financial Listed Companies at Karachi Stock Exchange. International Research Journal of Finance and Economics (84), pp.55-72.

Wei, Y., 2003. Comparative Corporate Governance: A Chinese Perspective. Published by Kluwer International. London.

Weisbach, M.,1988. Outside Directors and CEO Turnover. Journal of Financial Economics, 20(2),pp.431-460.

Weir, C., Laing, D., and McKnight, P.,.2002. Internal and External Governance Mechanisms: Their Impact on the Performance of Large UK Public Companies. Journal of Business Finance and Accounting, 29(6),pp.579-611.

Worldbank.org.,2011. Saudi Arabia, Data. [Online] Available at: http://data.worldbank.org/country/saudi-arabia [Accessed: 5 Feb 2013].

Yermack, D.,1996.Higher Market Valuation of Companies with a Small Board of Directors. Journal of Financial Economics, 40(2), pp.185-221.

Yusoff, W. and Alhaji, I.,2012. Corporate Governance and Firm Performance of Listed Companies in Malaysia. Journal of Trends and Development in Management Studies,1(2), pp.43-65.

Zattoni, A. and Udge, W., 2012. Corporate Governance and Initial Public Offerings: An International Perspective”. Published by Cambridge University Press. UK.

Zingales, L.,1998. "Corporate Governance" in The New Palgrave Dictionary of Economic and the Law. London: Macmillan, pp.497-502.

Zinkin, J., 2010. Challenges in Implementing Corporate Governance; Whose Business is it anyway?. Published by John Wiley \& Sons. China.

Zu, L.,2009. Corporate Social Responsibility, Corporate Restructuring and Firm's Performance. Published by Springer. China. 


\section{Appendix}

(Firms selected for analysis)

Table A.1: Firms selected for analysis

\begin{tabular}{|c|c|c|}
\hline Petrochemical Industries & Industrial Investment & Real Estate Development \\
\hline $\begin{array}{l}2330 \text { - Advanced Petrochemical } \\
\text { Company }\end{array}$ & $\begin{array}{l}1214 \text { - Al Hassan Ghazi } \\
\text { Ibrahim Shaker }\end{array}$ & $\begin{array}{l}4150 \text { - Arriyadh Development } \\
\text { Co. }\end{array}$ \\
\hline 2170 - Alujain Corporation & $\begin{array}{l}1213 \text { - Al Sorayai Trading And } \\
\text { Industrial Group Company }\end{array}$ & $\begin{array}{l}4300 \text { - Dar Alarkan Real Estate } \\
\text { Development Company }\end{array}$ \\
\hline $\begin{array}{l}2001 \text { - Methanol Chemicals } \\
\text { Company }\end{array}$ & $\begin{array}{l}2340 \quad-\quad \text { ALABDULLATIF } \\
\text { INDUSTRIAL INVESTMENT } \\
\text { CO. }\end{array}$ & $\begin{array}{l}4220 \text { - Emaar The Economic } \\
\text { City }\end{array}$ \\
\hline 2210 - Nama Chemicals Co. & 1212 - Astra Industrial Group & $\begin{array}{l}4250 \text { - Jabal Omar Development } \\
\text { Company }\end{array}$ \\
\hline $\begin{array}{ll}2060 \quad- & \text { National } \\
\text { Industrialization Co } & \end{array}$ & $\begin{array}{l}1210 \quad-\text { Basic Chemical } \\
\text { Industries Co }\end{array}$ & $\begin{array}{l}4310 \text { - Knowledge Economic } \\
\text { City }\end{array}$ \\
\hline $\begin{array}{l}2002 \text { - National Petrochemical } \\
\text { Company }\end{array}$ & $\begin{array}{l}2180 \text { - Filing and Packing } \\
\text { Materials Manufacturing Co. }\end{array}$ & $\begin{array}{l}4100 \text { - Makkah Construction and } \\
\text { Development Co. }\end{array}$ \\
\hline $\begin{array}{l}2380 \text { - Rabigh Refining and } \\
\text { Petrochemical Co }\end{array}$ & $\begin{array}{l}2220-\quad \text { National Metal } \\
\text { Manufacturing and Casting Co. }\end{array}$ & 4020 - Saudi Real Estate Co. \\
\hline $\begin{array}{l}2260 \text { - Sahara Petrochemical } \\
\text { Co. }\end{array}$ & $\begin{array}{l}1211 \text { - Saudi Arabian Mining } \\
\text { Company }\end{array}$ & 4090 - Taiba Holding Co. \\
\hline $\begin{array}{l}2020 \text { - Saudi Arabia Fertilizers } \\
\text { Co. }\end{array}$ & \multicolumn{2}{|l|}{2230 - Saudi Chemical Company } \\
\hline $\begin{array}{l}2010 \text { - Saudi Basic Industries } \\
\text { Corp }\end{array}$ & \multicolumn{2}{|l|}{4140 - Saudi Industrial Export Co } \\
\hline $\begin{array}{lll}2250 \quad-\quad \text { Saudi } & \text { Industrial } \\
\text { Investment Group } & \end{array}$ & \multicolumn{2}{|c|}{2300 - Saudi Paper Manufacturing Co. } \\
\hline 2310 - Saudi International & \multicolumn{2}{|c|}{2070 - Saudi Pharmaceutical Indust.\& Med. Appliances Corp. } \\
\hline
\end{tabular}




\begin{tabular}{|c|c|c|}
\hline Petrochemical Co & & \\
\hline $\begin{array}{l}2350 \quad-\quad \text { Saudi } \quad \text { Kayan } \\
\text { Petrochemical Company }\end{array}$ & \multicolumn{2}{|l|}{1201 - Takween Advanced Industries } \\
\hline $\begin{array}{l}2290 \quad-\quad \text { Yanbu National } \\
\text { Petrochemical Company }\end{array}$ & \multicolumn{2}{|c|}{2150 - The National Co. for Glass Industries } \\
\hline Hotel \& Tourism Industries & Media and Publishing & Transport \\
\hline $\begin{array}{l}1810 \text { - Al-Tayyar Travel Group } \\
\text { Holding Co. }\end{array}$ & $\begin{array}{l}4270 \text { - Saudi Printing and } \\
\text { Packaging Company }\end{array}$ & $\begin{array}{l}4040 \text { - Saudi Public Transport } \\
\text { Co. }\end{array}$ \\
\hline $\begin{array}{l}4010 \text { - Saudi Hotels \& Resort } \\
\text { Areas Co. }\end{array}$ & $\begin{array}{l}4210 \text { - Saudi Research and } \\
\text { Marketing Group }\end{array}$ & $\begin{array}{l}4110 \text { - Saudi Transport and } \\
\text { Investment Company }\end{array}$ \\
\hline 4170 - Tourism Enterprise Co. & $\begin{array}{l}4070 \text { - Tihama Advertising \& } \\
\text { Public Relations Co. }\end{array}$ & $\begin{array}{l}4030 \text { - The National Shipping } \\
\text { Co. of Saudi Arabia }\end{array}$ \\
\hline & & $\begin{array}{l}4260 \text { - United International } \\
\text { Transportation Company Ltd. }\end{array}$ \\
\hline Retail & Cement Industry & Energy \& Utilities Industries \\
\hline $\begin{array}{l}4001 \text { - Abdullah Al Othaim } \\
\text { Markets Company }\end{array}$ & $\begin{array}{l}3091 \text { - AL JOUF CEMENT } \\
\text { COMPANY }\end{array}$ & $\begin{array}{l}2080 \quad-\quad \text { National Gas } \& \\
\text { Industrialization Co. }\end{array}$ \\
\hline $\begin{array}{l}4200 \text { - Aldrees Petroleum \& } \\
\text { Transport Services Co. }\end{array}$ & 3010 - Arabian Cement Co & $\begin{array}{lll}5110 \quad-\quad \text { Saudi } & \text { Electricity } \\
\text { Company } & & \end{array}$ \\
\hline $\begin{array}{l}4290 \text { - Alkhaleej Training and } \\
\text { Education Company }\end{array}$ & 3003 - City Cement Co & Multi-Investment \\
\hline $\begin{array}{l}4004 \text { - Dallah Healthcare } \\
\text { Holding Company }\end{array}$ & $\begin{array}{l}3080-\text { Eastern } \text { Province } \\
\text { Cement Co. }\end{array}$ & 2140 - Al-Ahsa Development Co. \\
\hline $\begin{array}{lcc}4240 \quad-\quad \text { Fawaz } & \text { Abdulaziz } \\
\text { AlHokair Company } & \end{array}$ & 3001 - Hail Cement Company & $\begin{array}{l}4130 \text { - Al-Baha Investment and } \\
\text { Development co }\end{array}$ \\
\hline 4180 - Fitaihi Holding Group & $\begin{array}{lll}3002 \quad- & \text { Najran } & \text { Cement } \\
\text { Company } & & \end{array}$ & $\begin{array}{l}4080 \text { - Aseer Trading, Tourism \& } \\
\text { Manufacturing Co. }\end{array}$ \\
\hline
\end{tabular}




\begin{tabular}{|c|c|c|}
\hline 4190 - Jarir Marketing Co & $\begin{array}{l}3004 \text { - Northern Region Cement } \\
\text { Company }\end{array}$ & $\begin{array}{l}4280 \text { - Kingdom Holding } \\
\text { Company }\end{array}$ \\
\hline $\begin{array}{l}4002 \text { - Mouwasat Medical } \\
\text { Services Company }\end{array}$ & 3030 - Saudi Cement Company. & $\begin{array}{l}2120 \quad-\quad \text { Saudi Advanced } \\
\text { Industries Co. }\end{array}$ \\
\hline $\begin{array}{l}4160 \text { - National Agriculture } \\
\text { Marketing Co. }\end{array}$ & $\begin{array}{l}3050 \text { - Southern Province } \\
\text { Cement Co. }\end{array}$ & $\begin{array}{l}2030 \text { - Saudi Arabia Refineries } \\
\text { Co. }\end{array}$ \\
\hline $\begin{array}{l}4005 \text { - National Medical Care } \\
\text { Company }\end{array}$ & 3090 - Tabuk Cement Co. & $\begin{array}{l}2190 \text { - Saudi Industrial Services } \\
\text { Co. }\end{array}$ \\
\hline $\begin{array}{l}4050 \text { - Saudi Automotive } \\
\text { Services Co. }\end{array}$ & 3040 - The Qassim Cement Co & \\
\hline $\begin{array}{l}4006 \quad \text { - Saudi Marketing } \\
\text { Company }\end{array}$ & 3020 - Yamama Cement Compan & \\
\hline $\begin{array}{l}4003 \text { - United Electronics } \\
\text { Company }\end{array}$ & 3060 - Yanbu Cement Co. & \\
\hline Building \& Construction & $\begin{array}{l}\text { Agriculture } \quad \& \quad \text { Food } \\
\text { Industries }\end{array}$ & $\begin{array}{l}\text { Telecommunication } \\
\text { Information Technology }\end{array}$ \\
\hline $\begin{array}{l}1330 \text { - Abdullah A. M. Al- } \\
\text { Khodari Sons Company }\end{array}$ & $\begin{array}{l}6070 \text { - Al-Jouf Agriculture } \\
\text { Development Co. }\end{array}$ & $\begin{array}{l}7040 \quad-\quad \text { Etihad Atheeb } \\
\text { Telecommunication Company }\end{array}$ \\
\hline $\begin{array}{l}2320 \text { - AL-BABTAIN POWER } \\
\text { \&TELECOMMUNICATION } \\
\text { CO }\end{array}$ & 2280 - Almarai Company & 7020 - Etihad Etisalat Co \\
\hline 2200 - Arabian Pipes Company & $\begin{array}{l}4061 \text { - Anaam International } \\
\text { Holding Group CO. }\end{array}$ & $\begin{array}{lr}7030 \quad- & \text { Mobile } \\
\text { Telecommunications } & \text { Company } \\
\text { Saudi Arabia } & \end{array}$ \\
\hline 1302 - Bawan Company & $\begin{array}{l}6060 \quad-\quad \text { Ash-Sharqiyah } \\
\text { Development Company }\end{array}$ & $\begin{array}{l}7050 \text { - Saudi Integrated Telecom } \\
\text { Company }\end{array}$ \\
\hline $\begin{array}{l}2370 \text { - Middle East Specialized } \\
\text { Cables Co }\end{array}$ & $\begin{array}{l}6080 \text { - Bishah Agriculture } \\
\text { Development Co. }\end{array}$ & 7010 - Saudi Telecom \\
\hline
\end{tabular}




\begin{tabular}{|c|c|c|}
\hline $\begin{array}{l}1310 \text { - Mohammad Al Mojil } \\
\text { Group Company }\end{array}$ & 6001 - Halwani Bros & Multi-Investment \\
\hline $\begin{array}{l}2090 \text { - National Gypsum } \\
\text { Company }\end{array}$ & 6002 - Herfy Food Services Co & 2140 - Al-Ahsa Development Co. \\
\hline $\begin{array}{l}4230 \text { - Red Sea Housing } \\
\text { Services Company }\end{array}$ & 6090 - Jazan Development Co. & $\begin{array}{l}4130 \text { - Al-Baha Investment and } \\
\text { Development co }\end{array}$ \\
\hline $\begin{array}{l}2160 \text { - Saudi Arabian Amiantit } \\
\text { Co. }\end{array}$ & $\begin{array}{l}6010 \text { - National Agriculture } \\
\text { Development Co. }\end{array}$ & $\begin{array}{l}4080 \text { - Aseer Trading, Tourism \& } \\
\text { Manufacturing Co. }\end{array}$ \\
\hline 2110 - Saudi Cable Company & 6020 - Qassim Agriculture Co. & $\begin{array}{l}4280-\text { Kingdom Holding } \\
\text { Company }\end{array}$ \\
\hline 2040 - Saudi Ceramic Co. & $\begin{array}{l}6004 \text { - Saudi Airlines Catering } \\
\text { Company }\end{array}$ & $\begin{array}{l}2120 \quad-\quad \text { Saudi Advanced } \\
\text { Industries Co. }\end{array}$ \\
\hline $\begin{array}{l}2130 \quad-\quad \text { Saudi Industrial } \\
\text { Development Co. }\end{array}$ & 6050 - Saudi Fisheries Co. & $\begin{array}{l}2030 \text { - Saudi Arabia Refineries } \\
\text { Co. }\end{array}$ \\
\hline $\begin{array}{l}1320 \text { - Saudi Steel Pipe } \\
\text { Company }\end{array}$ & $\begin{array}{l}2270 \text { - Saudia Dairy and } \\
\text { Foodstuff .Co }\end{array}$ & $\begin{array}{l}2190 \text { - Saudi Industrial Services } \\
\text { Co. }\end{array}$ \\
\hline $\begin{array}{l}2360 \text { - Saudi vitrified clay pipes } \\
\text { co. }\end{array}$ & 2050 - Savola Group & \\
\hline $\begin{array}{l}1301 \text { - United Wire Factories } \\
\text { Company }\end{array}$ & 6040 - Tabuk Agriculture Develo & oment Co. \\
\hline $\begin{array}{l}2240 \quad-\quad \text { Zamil Industrial } \\
\text { Investment Co }\end{array}$ & 2100 - WAFRAH FOR INDUST & RY AND DEVELOPMENT \\
\hline
\end{tabular}

\section{Copyright Disclaimer}

Copyright for this article is retained by the author(s), with first publication rights granted to the journal.

This is an open-access article distributed under the terms and conditions of the Creative Commons Attribution license (http://creativecommons.org/licenses/by/3.0/). 